\title{
PINE FOREST SUCCESSION ON SANDY RIDGES WITHIN OUTWASH PLAIN (SANDUR) IN NERUSSA-DESNA POLESIE
}

\section{O. I. Evstigneev}

State Nature Reserve "Bryansky Les", Nerussa Station, Bryansk Oblast, 242180, Russia

E-mail:quercus_eo@mail.ru

\section{N. Korotkov}

Lomonosov Moscow State University, 1 Leninskiye gory, Moscow, 119991, Russia

E-mail:korotkovv@list.ru

\section{СУКЦЕССИИ СОСНОВЫХ ЛЕСОВ НА ПЕСЧАНЫХ ГРИВАХ ЗАНАРОВОЙ РАВНИНЫ В НЕРУССО-АЕСНЯСКОМ ПОЛЕСЬЕ}

\author{
О. И. Евстигнеев \\ Заповедник «Брянский лес», Россия, 242180, Брянская область, станция Нерусса \\ E-mail:quercus_eo@mail.ru
}

\section{В. Н. Коротков}

Московский государственный университет имени М. В. Ломоносова, 119991, Москва, Ленинские горы, 1 E-mail:korotkovv@list.ru

\begin{abstract}
Successional changes of pine forests were studied in outwash areas characterised by topography with ridges and depressions. The spatial series of pine forests of different stand ages and those that have not experienced the impact of human activities were analyzed. Pine forests in outwash areas form two successional series depending on the different ecotopes. The following successional series occurs at the tops of ridges: boreal green moss pine forest $\rightarrow$ boreal green moss - dwarf shrub forests $\rightarrow$ boreo-nemoral pine forest with admixture of birch, oak, spruce $\rightarrow$ nemoral polydominant spruce broad-leaved forest. Another successional series is formed on gentle ridge slopes: boreal polytric pine forest $\rightarrow$ boreal bilberry-polytric pine forest $\rightarrow$ boreo-nemoral pine forest with admixture of birch, oak, spruce $\rightarrow$ nemoral polydominant spruce broad-leaved forest. We show that ecotope has the leading role in the organisation of cenoses at the early stages of succession: green moss pine forests are formed at high and relatively dry relief sites (ridges) and polytric pine forests are formed on relatively wet ridge slopes. The ecotopic mosaic is complicated by the vegetation pattern created by animals (e.g., seed hawkers) at the intermediate stages of succession. Zoochoric species appear in the community: Vaccinium vitis-idaea, Convallaria majalis, Sorbus aucuparia and Quercus robur more often take root at the top of ridges; Vaccinium myrtillus, Frangula alnus and Picea abies grow on the slopes. The mosaic created by trees is imposed on a mosaic caused by ecotopes and animals at the final stages of succession: tree-fall gaps appear in the place of old dead trees with tree undergrowth. As a result, a heterogeneous community with a number of asynchronously developing gaps is formed in place of homogeneous pine forest.
\end{abstract}

Key words: pine forests, succession, zoochory, outwash areas.

For citation: Evstigneev O.I., Korotkov V.N. Pine Forest Succession on Sandy Ridges within Outwash Plain (Sandur) in Nerussa-Desna Polesie. Russian Journal of Ecosystem Ecology. 2016;1(3). Available from: https://doi.org/10.21685/2500-0578-2016-3-2

Аннотация. Сукцессионные изменения сосняков изучали на примере зандровых местностей, которые характеризуются гривисто-западинным рельефом. При этом анализировались пространственные ряды сосняков, которые отличались возрастом древостоя и не испытывали влияния хозяйственной деятельности человека. Сосняки зандровых местностей формируют два сукцессионных ряда. Они развиваются в разных экотопических условиях. На вершинах грив выделяется следующий сукцессионный ряд: бореальный сосняк зеленомошный $\rightarrow$ бореальный сосняк кустарничково-зеленомошный $\rightarrow$ бореально-неморально березоводубово-елово-сосновый лес $\rightarrow$ неморальный полидоминантный елово-широколиственный лес. На пологих склонах грив формируется другой сукцессионный ряд: бореальный сосняк долгомошный $\rightarrow$ бореальный сосняк чернично-долгомошный $\rightarrow$ бореально-неморальный березово-дубово-елово-сосновый лес $\rightarrow$ немо- 
ральный полидоминантный елово-широколиственный лес. Эти ряды показывают, что для повышенных и склоновых участков зандровых местностей характерен конвергентный путь развития сообществ: из двух разных ценозов бореального состава формируется один вариант сообществ неморального состава - полидоминантный елово-широколиственный лес. Показано, что на первых этапах сукцессии ведущая роль в организации ценозов принадлежит экотопу: на повышенных относительно сухих участках рельефа (гривах) формируются сосняки зеленомошные, на относительно влажных склонах грив - сосняки долгомошные. На промежуточных этапах сукцессии экотопическая мозаика усложняется растительным узором, который создают животные - разносчики семян. В сообществе появляются зоохорные виды растений: на вершинах грив чаще приживаются Vaccinium vitis-idaea, Convallaria majalis, Sorbus aucuparia и Quercus robur, на склонах - Vaccinium myrtillus, Frangula alnus и Picea abies. На заключительных этапах на мозаику, обусловленную экотопом и животными, накладывается мозаика, создаваемая деревьями: на месте гибели старых деревьев появляются «окна», которые зарастают подростом. В результате на месте однородного сосняка формируется сообщество с множеством асинхронно развивающихся «окон».

Ключевые слова: сосняки, сукцессия, зоохория, зандровая местность.

\section{Introduction}

According to the historical analysis of natural resource management in the territory of Eastern Europe, modern vegetation cover was formed under the influence of centuries-old human activity [1].

It is radically different from the biocenotic cover that existed before active anthropogenic changes in the Neolithic Period of the middle Holocene [2-8]. Specific examples describing anthropogenic transformations of vegetation during the Holocene can be found in works devoted to the Moscow Region [9-11], Kaluga Region [12, 13], the western slopes of the Volga Uplands [14] and NerussaDesna Polesie [15-18].

Nerussa-Desna Polesie is situated in the nemoral forest zone [3, 19]; however, the proportion of nemoral forests in this physiographic region accounts for only $32 \%$ of the territory. The largest area is covered by boreal forest (48\%), among which pine forests (Pinus sylvestris L.) dominate. Wooded swamp, grass moor, sphagnum bogs $(19 \%)$ and meadows $(1 \%)$ are presented in the rest of the area. Previous studies showed that natural resource management in the past had determined the discrepancy between the modern vegetation of Nerussa-Desna Polesie and the zonal vegetation $[17,18,20]$. Another possible pathway for the reconstruction of preagricultural (climax, undisturbed) communities is analysis of successional changes of forest communities that are untouched by human intervention.

This paper has two main aims: (1) to analyse the succession direction of the pine forests that dominate in the territory of Nerussa-Desna Polesie and (2) to identify the type and appearance of the pre-agricultural forest community of this physiographic region.

\section{Materials and methods}

Nerussa-Desna Polesie is located in the southeastern part of the Bryansk Region of Russia. Polesie is a low-lying sandy forest plain with significant bogginess [21]. The plain is formed by alluvial and fluvioglacial sediments of the Quaternary period. The area is located at $52.5^{\circ} \mathrm{N}$, $34.0^{\circ} \mathrm{E}$ and has an area of 280,000 hectares. The climate is temperate continental. This physiographic region is located in a nemoral forest zone $[3,19]$.

Nerussa-Desna Polesie refers to a Polesie subprovince of the Eastern European province of broadleaved forests according to botanical and geographical regionalisation [3]. Nemoral forests belong to the class Querco-Fagetea Br.-Bl. et Vlieger in Vlieger $1937 \mathrm{em}$. Klika 1939, and boreal forests to the class Vaccinio-Piceetea Br.-B1. in Br.-Bl., Sissingh et Vlieger 1939 according to the eco-floristic classification of vegetation [22]. In the state nature reserve "Bryansky Les" ("Bryansk Forest"), which was established in 1987 within the Nerussa-Desna Polesie, human economic activity is completely prohibited. We found the forest communities where economic activity had stopped long before the organisation of the reserve. This allowed us to analyse development trends of forest communities.

Pine forests were chosen as the object of study as they prevail in Nerussa-Desna Polesie, accounting for over $50 \%$ of the forest area [23]. It is believed that the zonal features are most pronounced in the communities located on the watershed plateau [24, 25]. Therefore successional transformations of communities were studied in the territory of outwash areas, which are represented by sandy watershed plains with altitudes of 155 to $165 \mathrm{~m}$. The abundance of ridges and depressions is typical for out- 
wash areas. The relative excess of relief is typically 1 to $3 \mathrm{~m}$ while ridges with elevation of $5 \mathrm{~m}$ are less common. The lithological profile is dominated by 10 to $15 \mathrm{~m}$ of sand underlain by loams. The depth of groundwater is 1.0 to $3.5 \mathrm{~m}$. Soils are characterised by a small provision of elements of mineral nutrition and high acidity $[18,26]$.

Forest successions are characterised by long duration, which is significantly higher than the life of a researcher. Therefore drawing on the experience of other studies [2,3] we selected spatial series of communities that are considered as time series. In this case the following rules are followed: (1) communities of the same spatial series are located in similar conditions of lithological composition and hydrological regime (i.e., within one type of site); (2) these communities have similar economic impact in the past; (3) they are represented by pine cultures that formed on the clearing areas; (4) these forest plantations were damaged several times by ground fires before protection in the reserve and (5) pine plantations are of differed age so it is possible to build a successional series of communities.

Vegetation data sampling was performed at ten temporary square sample plots of a fixed size $\left(100 \mathrm{~m}^{2}\right)$ randomly placed within a forest type. Eighty geobotanical descriptions were carried out in total. A list of plant species with species abundance was made for each forest layer of the sample plots. Species abundance in each layer was assessed using the Braun-Blanquet cover scale [27].

Vascular plant diversity was assessed using the following indicators: species richness, species density, number of species in different ecologicalcoenotic groups (ECG) [28]. Species richness is the total number of plant species on the ten sample plots within each forest type. Species density is calculated as the average number of species per sample plot within a forest type.

Following the Russian botanist Nitsenko [29], we define an ECG as a group of species that are similar in ecological features and in constancy with the occurrence of vegetation communities of different types. The ECG concept is often used in Russia, though variability regarding group specification commonly occurs [30]. We group vascular plant species following Smirnova and Zaugolnova [28, 30, 31]. ECG classification is available on the site of the Institute of Mathematical Problems of Biology in the Russian Academy of Science (http://www.impb.ru/index.php?id=div/ lce/ecg). The ratio of ECG was determined by total list of species occurring on 10 sample plots.

Individual trees at different ontogenetic stages were analysed and the vitality of trees was assessed on sample plots of 1 ha. All trees were subdivided into groups based on height: (1) $50 \mathrm{~cm}$ or (2) more than $50 \mathrm{~cm}$. Tree sampling of the first group of trees was performed on five sample plots of $100 \mathrm{~m}^{2}$. Tree sampling of the second group of trees was performed on sample plots of 1 ha. The ontogenetic stages of tree species are as follows: $j-$ juvenile plant; $i m_{1}$ and $i m_{2}$ - immature plant of the first and second subgroups, respectively; $v_{1}$ and $v_{2}$ - virginile plant of the first and second subgroups, respectively; $g_{1}$ - young reproductive plant; $g_{2}-$ mature generative plant; $g_{3}$ - old generative plant [32-35]. To assess the dynamics of the forest vegetation, we used an earlier developed method based on the analysis of the ontogenetic structure of tree populations [36-37].

\section{Results}

\section{Features of nature management in the Nerussa-Desna Polesie territory}

Previously it was shown that the discrepancy between the boreal composition of modern forest vegetation of Nerussa-Desna Polesie and the zone of nemoral forest where the physiographic region is located was determined not only by edaphic conditions but also by peculiarities of the past nature management [17]. The analysis of nature management history showed that from the Bronze Age to the 1920's slash-and-burn agriculture was widely practiced in the Polesie Region [38]. Materials from the Bryansk Region State Archive, the Russian State Archive of Ancient Acts, the Russian State Historical Archive, forest inventory maps $(1960,1989)$ as well as literary sources [39] show that different types of cutting were conducted in the territory of Nerussa-Desna Polesie for a long time, as well as man-made fires. Peasants used fire for cleaning forest hayfields and meadows, as well as for the elimination of forest residue at logging sites. Fire is often overlooked but can ruthlessly destroy forest vegetation over large areas.

Frequent fires combined with logging over many centuries almost completely destroyed the humusaccumulative horizon. The remaining sand substrate, with its intense flushing condition, became unfavorable for most vascular plants with high soil nutritional needs. Only bryophytes and some boreal vascular plants, which do not have high mineral nutritional element demands, survived in the sandy soils. In addition, Scots Pine cultures were created actively in the sand according to the circular of the Russian Forest Department of the 19th century [40]. Oligotrophic properties of pines [41] proved to be useful for their cultivation in large sandy areas. As a result, pine forests composed of boreal species were formed on the most part of the outwash terrain $[18,42]$. 


\section{Succession transformation of pine forests} in the Nerussa-Desna Polesie territory

The spatial structure of monodominant pine communities on outwash terrain is defined by the ridge-depression topography (Fig. 1). It is believed that flowing waters had formed this relief on laminose and without-rubble sands [43]. Currently, most of the boreal forest at the top of ridges in the outwash terrain is represented by green moss pine forest. On the slopes polytric pine forests are found and in the depressions sphagnum pine forests are found. Two successional series of communities are analysed in this paper: (1) those on the tops of ridges and (2) those on the gentle slopes of the ridges. The communities differ not only in terms of species composition but also in the character of succes- sional changes of these ecotopes. We will consider these features in the following sections.

Succession changes of pine forests at the tops of ridges (see Fig. 1, T). Poor, dry, sod-podzolic sandy soils with deep groundwater up to 1.5 to $3.5 \mathrm{~m}$ are characteristic of these habitats in the early stages of succession. Four stages of pine forests succession, which follow each other consistently, are allocated here: boreal green moss pine forest $\rightarrow$ boreal green moss-dwarf shrub forests with oak undergrowth (Quercus robur L.) $\rightarrow$ boreo-nemoral pine forest with admixture of birch (Betula spp.), oak (Quercus robur L.), spruce (Picea abies (L.) Karst) with undergrowth of Tilia cordata Mill., Acer platanoides L. and with an understorey of Corylus avellana L. $\rightarrow$ nemoral polydominant spruce broad-leaved forest.

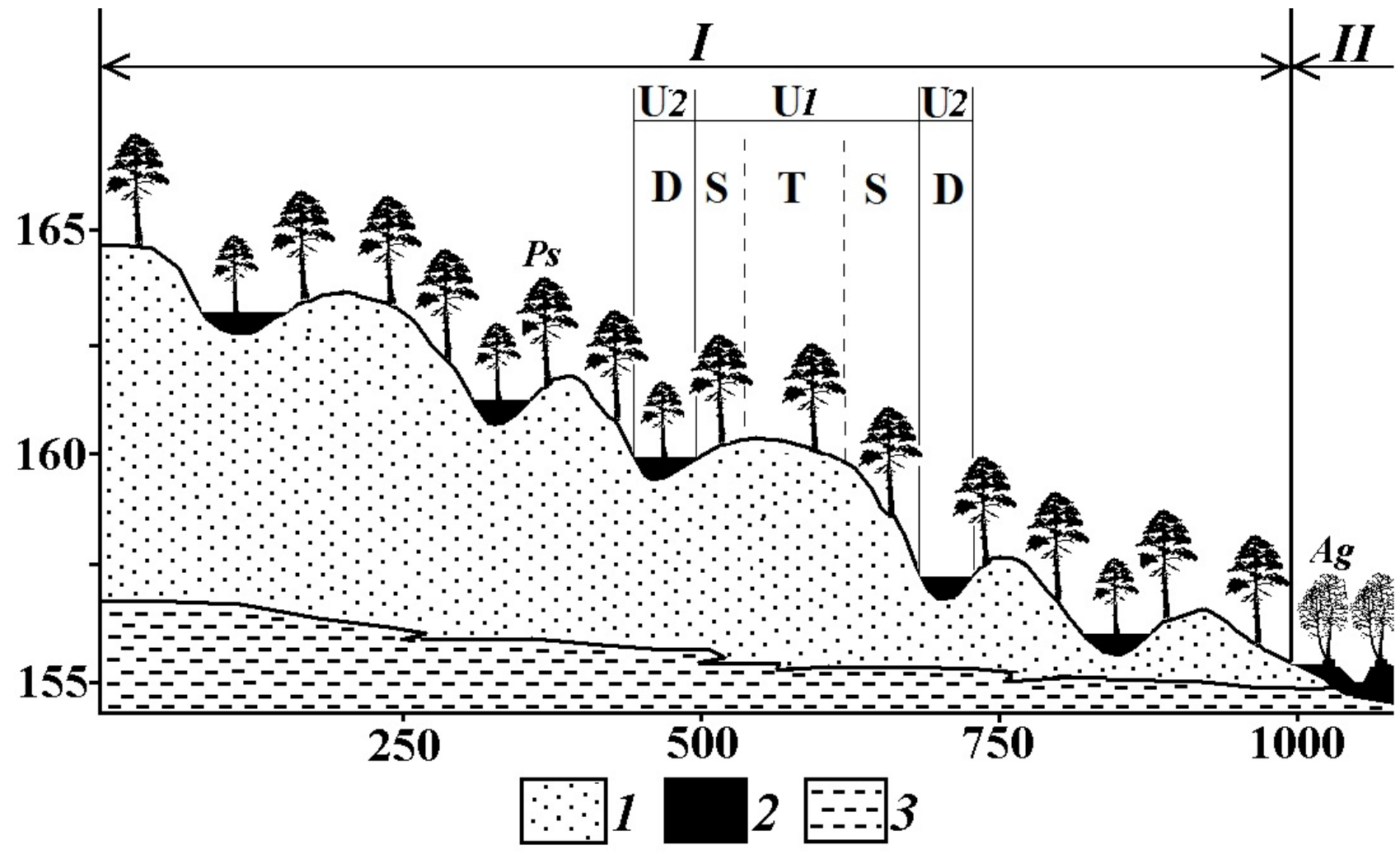

Fig. 1. Landscape profile of outwash sand locality (I), which is adjacent to the peaty areas of the floodplain of the small river (II). Tracts of outwash areas: $U_{1}$ - ridge, $U_{2}-$ inter-ridge depression (D). Facies of ridges:

$T$ - the top of ridges, $S$ - the slopes of ridges. Quaternary sediments: 1 - sand, 2 - peat, 3 - loam. Tree species:

Ps - Pinus sylvestris, Ag - Alnus glutinosa. A thick vertical line shows the boundary between the localities.

Thin vertical lines show the boundaries between the natural boundaries. The boundaries between facies are shown by vertical dotted lines. Horizontal axis - profile length in metres; vertical axis - height above the sea level in metres

The first stage: boreal green moss pine forest (Fig. 2, 1T; Fig. 3, 1). These communities are represented mainly by pine cultures ( 20 to 40 years) that repeatedly experienced ground fires before the organisation of nature reserve. Individuals of $v$ and $g_{l}$ stages are dominant in the tree stand. Undergrowth of woody plants is weak (a total projective cover degree of less than $5 \%$ ) because of frequent extermination by fire. Undergrowth is composed of Betula pendula Roth, Quercus robur, Frangula alnus Mill. and Sorbus aucuparia L. These plants presented solely immature individuals of coppice originating in the first years after a ground fire. Sometimes there are $v$ individuals of Quercus robur and Betula pendula, which due to their thick bark survived after ground fire keeping cambium 
at the base part of trunk. $J$ and im seed individuals of Quercus robur occasionally appear in the community. Jay (Garrulus glandarius (Linnaeus)) and nutcracker (Nucifraga caryocatactes (Linnaeus)) carry acorns. These birds move acorns over a distance of approximately $450 \mathrm{~m}[44,45]$.

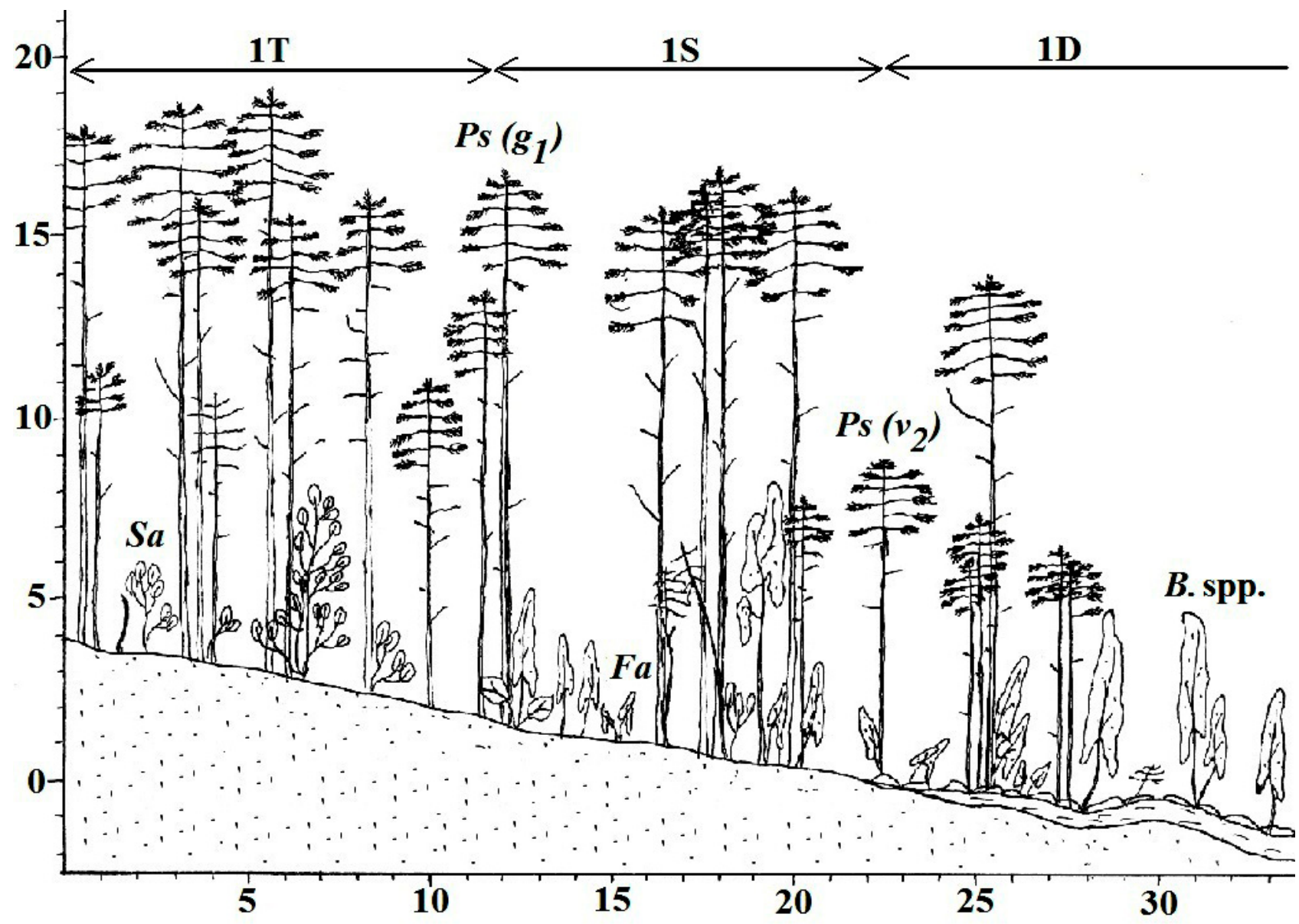

Fig. 2. Vertical structure of pine forests in the first stage of succession. Communities: $1 T$ - boreal green moss pine forest on top of the ridge, $1 S$ - boreal polytric pine forest on a gentle slope of the ridge, $1 D$ - sphagnum pine forest in depressions. Plant species: B.spp. - Betula pendula and B. pubescens, Fa - Frangula alnus, Ps - Pinus sylvestris, $\mathrm{Sa}$ - Sorbus aucuparia. Ontogenetic stages: $v_{2}-$ virginal plant of first subgroup, $g_{1}-$ young generative plant. Horizontal axis - profile length in metres; vertical axis - height above water level in metres

Frequent ground fires before the creation of the reserve led to the dominance of bryophytes in the ground cover. Green mosses Pleurozium schreberi (Brid.) Mitt. and Dicranum scoparium Hedw. dominate here and their projective cover degree reaches $100 \%$. Because of abundant sporulation these species first colonise exposed substrate arising from ground fires. The rapid formation of moss cover is provided by the fact that individual patches of bryophytes are stored in areas unaffected by the fire. Fire eliminates the potential invasion of herbs and dwarf shrubs (whose degree of coverage is no more than $15 \%$ ) and species richness ( 15 species per $\left.100 \mathrm{~m}^{2}\right)(\mathrm{Ta}$ ble 1). Only single plants of boreal, piny and dry meadow groups survived. Renewal buds of Calamagrostis epigeios (L.) Roth are protected by a layer of soil from fire damage and renewal buds of cespitose grass Festuca ovina L. are protected by vaginate leaves. Small areas of litter not affected by fire contain viable seeds of Calluna vulgaris (L.) Hull, Melampyrum pratense L. and Solidago virgaurea $\mathrm{L}$., as well as fragments of viable rhizomes of Peucedanum oreoselinum (L.) Moench, Vaccinium vitis-idaea L. and V. myrtillus L.

Phase duration is determined by the time required for the formation of a dense cover of dwarf shrubs. The distance between the surviving partial clumps of Vaccinium vitis-idaea and $V$. myrtillus is 5 to $10 \mathrm{~m}$ and the average annual growth of these species of rhizomes is 10 to $20 \mathrm{~cm} \mathrm{[46]} \mathrm{in} \mathrm{green}$ moss pine forest. In this case, the dwarf shrubs can fully close in 15 to 25 years. Periodic ground fires may delay the development of dwarf shrub synusia for a long time outside the reserve. It is therefore possible to find 120-year old green moss pine forests. 


\section{I}

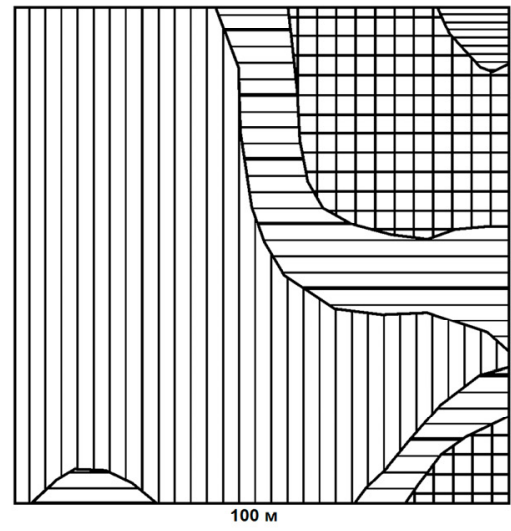

II

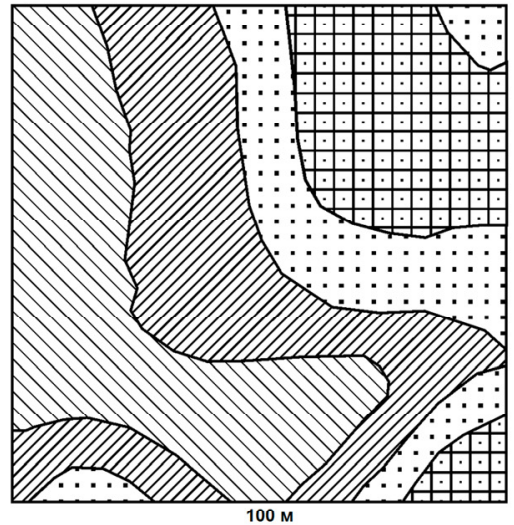

$100 \mathrm{M}$
IV

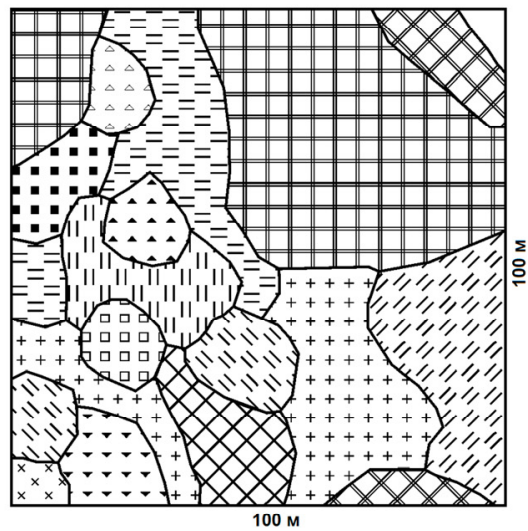

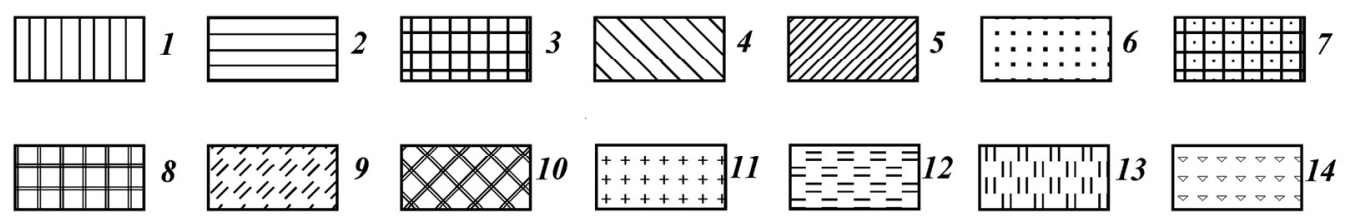

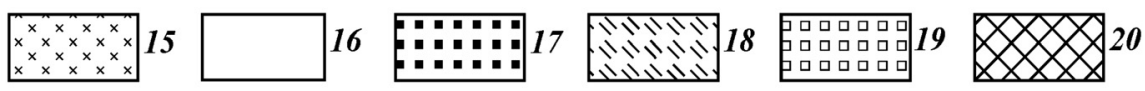

Fig. 3. Spatial structure of pine forest at different stages of succession in outwash terrain. Succession stages: I stage - 35-year old pine plantation, II stage - 60- year old pine plantation, III stage - missed picture, IV stage 120-year old spruce broad-leaved forest. Parcels (communities): 1 - Pinus sylvestris - Pleurozium schreberi; 2 - Pinus sylvestris - Polytrichum commune; 3 - Pinus sylvestris - Sphagnum falax; 4 - Pinus sylvestris - Vaccinium vitis-idaea -

Pleurozium schreberi; 5 - Pinus sylvestris - Vaccinium myrtillus - Pleurozium schreberi; 6 - Pinus sylvestris Vaccinium myrtillus - Polytrichum commune; 7 - Pinus sylvestris - Oxycoccus palustris - Sphagnum falax; 8 - Betula pubescens - Carex lasiocarpa; 9 - Pinus sylvestris + Quercus robur + Picea abies - Picea abies + Tilia cordata -

Convallaria majalis + Vaccinium myrtillus; $10-$ Pinus sylvestris + Quercus robur + Picea abies - Picea abies + Acer platanoides - Convallaria majalis + Stellaria holostea; 11 - Quercus robur + Picea abies - Picea abies + Corylus avellana -

Carex pilosa + Convallaria majalis; 12 - Quercus robur + Acer platanoides - Picea abies + Corylus avellana - Stellaria

holostea; 13 - Quercus robur - Quercus robur + Acer platanoides - Stellaria holostea; 14 - Quercus robur + Tilia cordata - Picea abies + Corylus avellana - Carex pilosa; 15 - Quercus robur + Picea abies - Picea abies + Corylus avellana -

Stellaria holostea; 16 - Pinus sylvestris - Quercus robur + Picea abies + Betula pendula - Carex pilosa + Stellaria holostea; 17 - gap with undergrowth of Quercus robur + Picea abies + Fraxinus excelsior; 18 - gap with undergrowth of Quercus robur + Picea abies; 19 - gap with undergrowth of Tilia cordata + Picea abies; 20 - gap with undergrowth of Picea abies + Betula pendula + Corylus avellana

Table 1

Diversity indices (vascular plants) of forest communities at different stages of succession at the tops of ridges on outwash terrain

\begin{tabular}{|c|c|c|c|c|}
\hline Diversity indices & 1 stage & 2 stage & 3 stage & 4 stage \\
\hline Number of sample plots & 10 & 10 & 10 & 10 \\
\hline Average number of species per $100 \mathrm{~m}^{2}$ & 15.3 & 14.2 & 34.8 & 36.4 \\
\hline Range of species number per $100 \mathrm{~m}^{2}$ & $12-18$ & $11-18$ & $22-53$ & $29-43$ \\
\hline Total number of species on 10 sample plots & 33 & 28 & 78 & 76 \\
\hline \multicolumn{5}{|c|}{ Number of species (and per cent**) of ecological-coenotic species group on 10 sample plots } \\
\hline The boreal forest group & $14(42.4)$ & $10(35.7)$ & $16(20.5)$ & $12(15.8)$ \\
\hline The piny group (edge boreal group) & $8(24.3)$ & $9(32.1)$ & $10(12.8)$ & $3(4.0)$ \\
\hline The nemoral forest group & $5(15.2)$ & $5(17.9)$ & $26(33.3)$ & $45(59.2)$ \\
\hline The nemoral edge group & $1(3.0)$ & $1(3.6)$ & $3(3.8)$ & $1(1.3)$ \\
\hline The dry meadow group & $4(12.1)$ & $2(7.1)$ & $12(15.4)$ & $1(1.3)$ \\
\hline The wet meadow group & - & - & $8(10.3)$ & $2(2.6)$ \\
\hline The nitrophilous forest group & $1(3.0)$ & $1(3.6)$ & $1(1.3)$ & $8(10.6)$ \\
\hline The nitrophilous edge group & - & - & $1(1.3)$ & $2(2.6)$ \\
\hline The water-marsh group & - & - & $1(1.3)$ & $1(1.3)$ \\
\hline Alluvial meadow group & - & - & - & $1(1.3)$ \\
\hline
\end{tabular}

Footnote. ${ }^{* *}$ - number of species at 10 sample plots (area of each sample plot $100 \mathrm{~m}^{2}$ ) is taken as $100 \%$. 
The second stage: boreal green moss - dwarf shrub forests with oak undergrowth (Fig. 3, II). Two variants of the communities are presented here. The first variant of community, the cowberry green moss pine forests are located at the tops of sandy ridges, and the second variant, bilberry green moss pine forests are located on sloping surfaces (Figs. 3-6). Usually, young and mature generative pine trees represent the upper tree layer.

The lack of ground fires over the last 25 to 50 years resulted in the following changes in the community. Firstly, a pronounced layer of shrubs and tree undergrowth with projective cover of 15 to $20 \%$ has been formed. Picea abies (L.) Karst. appears in this composition in addition to Quercus robur, Betula pendula, Sorbus aucuparia and Frangula alnus. Some individuals reach $g_{1}$ ontogenetic stage in Betula pendula coenopopulations and $v$ stage in coenopopulations of Quercus robur and Picea abies. The number of $j$ and $i m$ individuals in coenopopulations of Frangula alnus and Sorbus aucuparia increases 10 - to 30 -fold in comparison to the previous plant community. This is due to vegeta- tive propagation of individuals and seed drift from surrounding communities. In addition, virginile and young generative undergrowth trees provide a convenient perch for the birds that actively spread the seeds of Frangula alnus and Sorbus aucuparia.

Secondly, coverage of bryophytes decreases in ground cover and the coverage of dwarf shrubs and herbs increases. Dwarf shrubs are mainly represented by Vaccinium vitis-idaea and $V$. myrtillus. Cover of xeromorphic Vaccinium vitis-idaea usually develops at the tops of sandy ridges and cover of mesomorphic $V$. myrtillus on slopes. The relatively rapid formation of a dwarf shrub layer is determined by three factors: (1) species with low soil mineral nutrient demands [47]; (2) vegetative growth of individuals and (3) seed drift from surrounding areas. Birds and mammals disperse seeds of Vaccinium vitis-idaea and V. myrtillus [48-51] and it is observed that individuals of these species originating from seed can appear up to three or four hundred metres from the fruit-bearing plants. The average species richness of the community is 14 species of vascular plants (see Table 1).

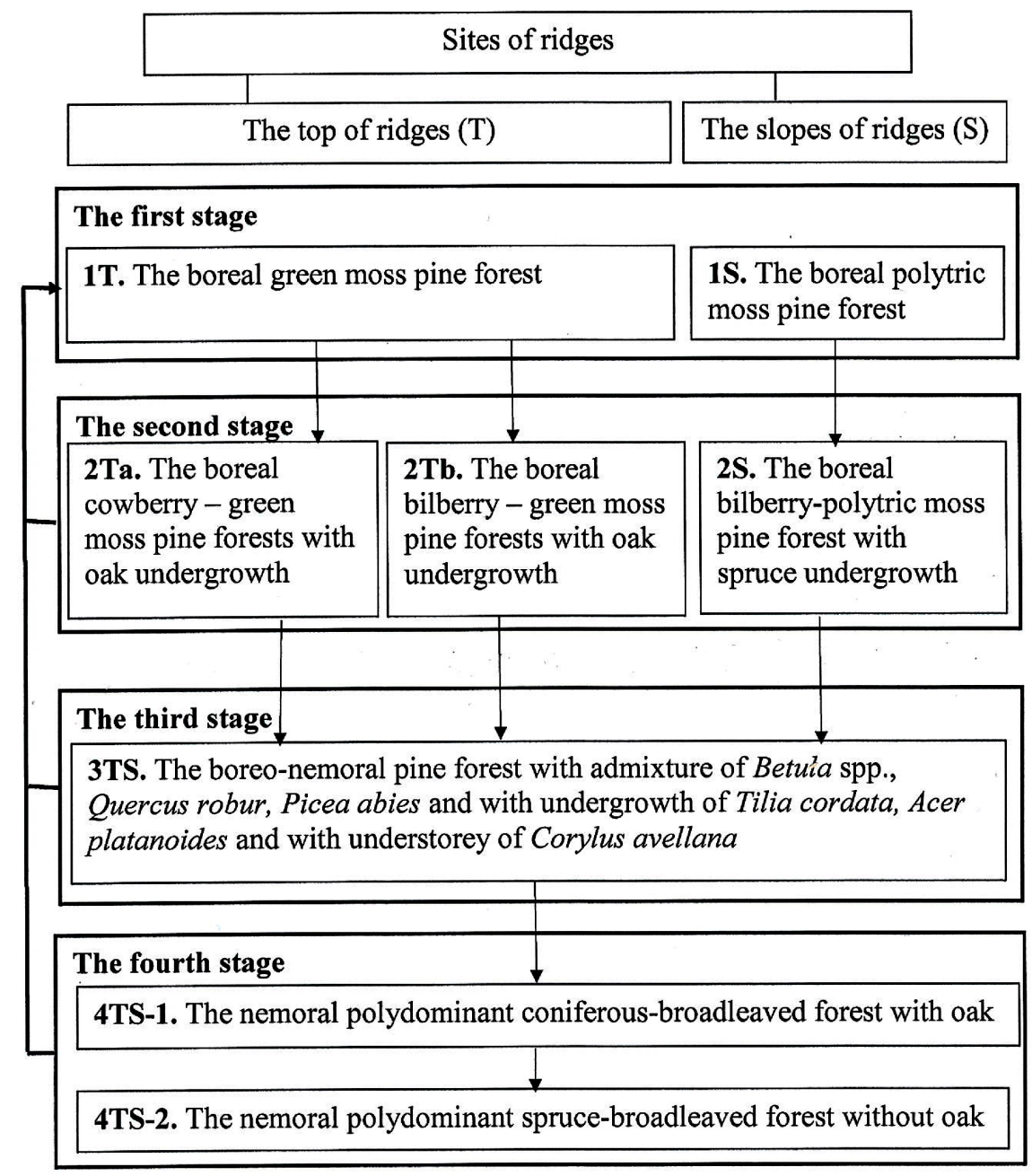

Fig. 4. Succession directions of pine forests on different ecotopes of outwash plains. Thin arrows succession of communities defined by the introduction of tree plants. Thick arrows - transformation of communities under the influence of fires and felling with subsequent planting of pines 


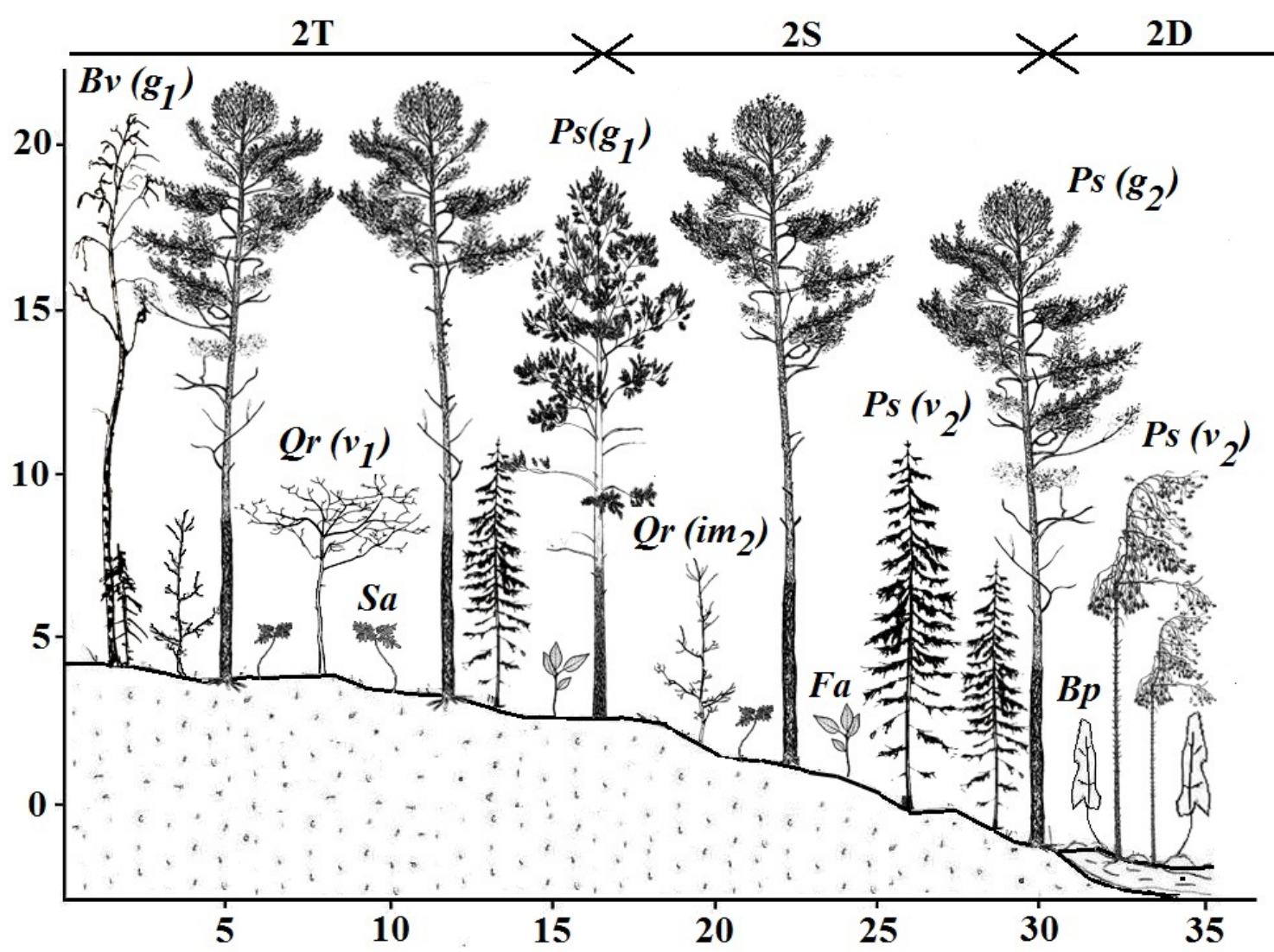

Fig. 5. Vertical structure of pine forests during the second stage of succession. Communities: $2 T$ - boreal green moss - dwarf shrub pine forest with oak undergrowth at the top of the ridge, $2 S$ - boreal bilberry-polytric pine forest with spruce on a gentle slope of ridge, $2 D$ - tussock cottongrass / sphagnum pine forest in the depressions. Plant species: Bv - Betula pendula, Bp - B. pubescens, Fa - Frangula alnus, Pa - Picea abies, Ps - Pinus sylvestris, $\mathrm{Sa}$ - Sorbus aucuparia, Qr - quercus robur. Ontogenic state of trees: $\mathrm{im}_{2}$ - immature plant of second subgroup, $v_{1}$ - virginile plant of first subgroup, $v_{2}$ - virginile plant of first subgroup, $g_{1}-$ young generative plant, $g_{2}-$ mature

generative plant. Horizontal axis - profile length in metres; vertical axis - height above water level in metres

Phase duration is determined by the time necessary for Quercus robur and Picea abies undergrowth to form a closed canopy over the layer of dwarf shrubs and corresponds to the length of its virginile ontogenetic stage, which is 40 to 50 years.

The third stage: boreo-nemoral pine forest with admixture of birch (Betula spp.), oak (Quercus robur), spruce (Picea abies) with undergrowth of Tilia cordata, Acer platanoides and an understorey of Corylus avellana (see Fig. 4, 3TS). Mainly mature generative pine and birch trees represent the tree canopy layer. The total vegetation cover of the understorey layer is 60 to $80 \%$. The maximum number of Quercus robur and Picea abies undergrowth accounts for the $v$ ontogenetic stage. A shady canopy of Quercus robur, Betula pendula and Picea abies creates favourable conditions for seedlings of Acer platanoides, Tilia cordata and Malus sylvestris Mill. Juvenile, immature and virginile individuals were represented in coenopopulations of these species over the sixty years after the last ground fire. Shrub synusia replenished by Corylus avellana and Euonymus verrucosa Scop. Corylus avellana has time to form a dense undergrowth layer consisting of generative individuals. Seeds of trees and shrubs are brought by animals from refuges of spruce broad-leaved forests located in small river valleys in the moraineoutwash areas (see Fig. 6): Sitta europaea Linnaeus, Parus palustris Linnaeus, P. montanus Baldenstein and $P$. ater Linnaeus pull apart and store Acer platanoides and Tilia cordata seeds [45]; Garrulus glandarius and Nucifraga caryocatactes disperse Corylus avellana seeds [52]; Sylvia spp. and Turdus spp. eat and disperse Euonymus verrucosa seds [53], and other mammal species help distribute Malus sylvestris [54-56]. The study of tree species regeneration showed that seedlings of Tilia cordata and Corylus avellana appear within $200 \mathrm{~m}$ of the parent plant; seedlings of Acer platanoides and Euonymus verrucosa appear $260 \mathrm{~m}$ from the parent plant and seedlings of Malus sylvestris appear $960 \mathrm{~m}$ from the parent plant [57].

Increasing crown density of the upper layers promotes the following changes in the ground cover: (1) bryophytes and dwarf shrubs disappear almost completely; (2) the average species richness of vascular plants is 35 species and (3) dominance in 
herb synusia proceeds to nemoral group (see Table 1). However, high participation of boreal plants (Dryopteris carthusiana (Vill.) H. P. Fuchs, Maianthemum bifolium (L.) F. W. Schmidt, Melampyrum pratense, Orthilia secunda (L.) House, Pyrola rotundifolia L., Rubus saxatilis L.) still remains. Among the nemoral species to appear are: $A e$ gopodium podagraria L., Asarum europaeum L., Carex pilosa Scop., Galeobdolon luteum Huds., Galium intermedium Schult., Lathyrus vernus (L.) Bernh., Melica nutans L., Milium effusum L., Platanthera bifolia (L.) Rich., Stellaria holostea L. and Viola mirabilis L. Ingrowth of these species in a community is determined by shading that creates the undergrowth layer. Observations showed that the seed individuals of Aegopodium podagraria, Carex pilosa and Stellaria holostea appear 200 to $300 \mathrm{~m}$ from the generative plants that survived in nemoral flora refugia, that being the spruce broad-leaved forests along the banks of small rivers and streams (see Fig. 5). Primarily cloven-hoofed mammals transfer seeds over this distance. They can be moved over a distance of 80 to $600 \mathrm{~m}$ during the time interval between regular defecation [58, 59].

Phase duration is determined by time that is needed for Quercus robur and Picea abies to grow to the upper tree layer and due to the length of their $g_{l}$ stage ( 30 to 50 years).

The fourth stage: nemoral polydominant spruce broad-leaved forest (Fig. 3, IV; Fig. 4, 4TS-1; Fig. 7, 4T). Recovery succession leads to the formation of polydominant coniferous broadleaved forest where nemoral plant species dominate after a long-term absence of fire (120 years or more). Old pine trees gradually fall from the stands but oak, spruce and birch are located in the tree canopy layer in these communities. Treefall gaps appear at sites of dead trees (see Fig. 3, 18-20). Full-membered coenopopulations of shade-tolerant tree species (Picea abies, Acer platanoides, Tilia cordata), which first invade in post-fire pine forest, are formed. At the same time, undergrowth of Padus avium Mill., Ulmus glabra Huds. and Fraxinus excelsior L. appears here.

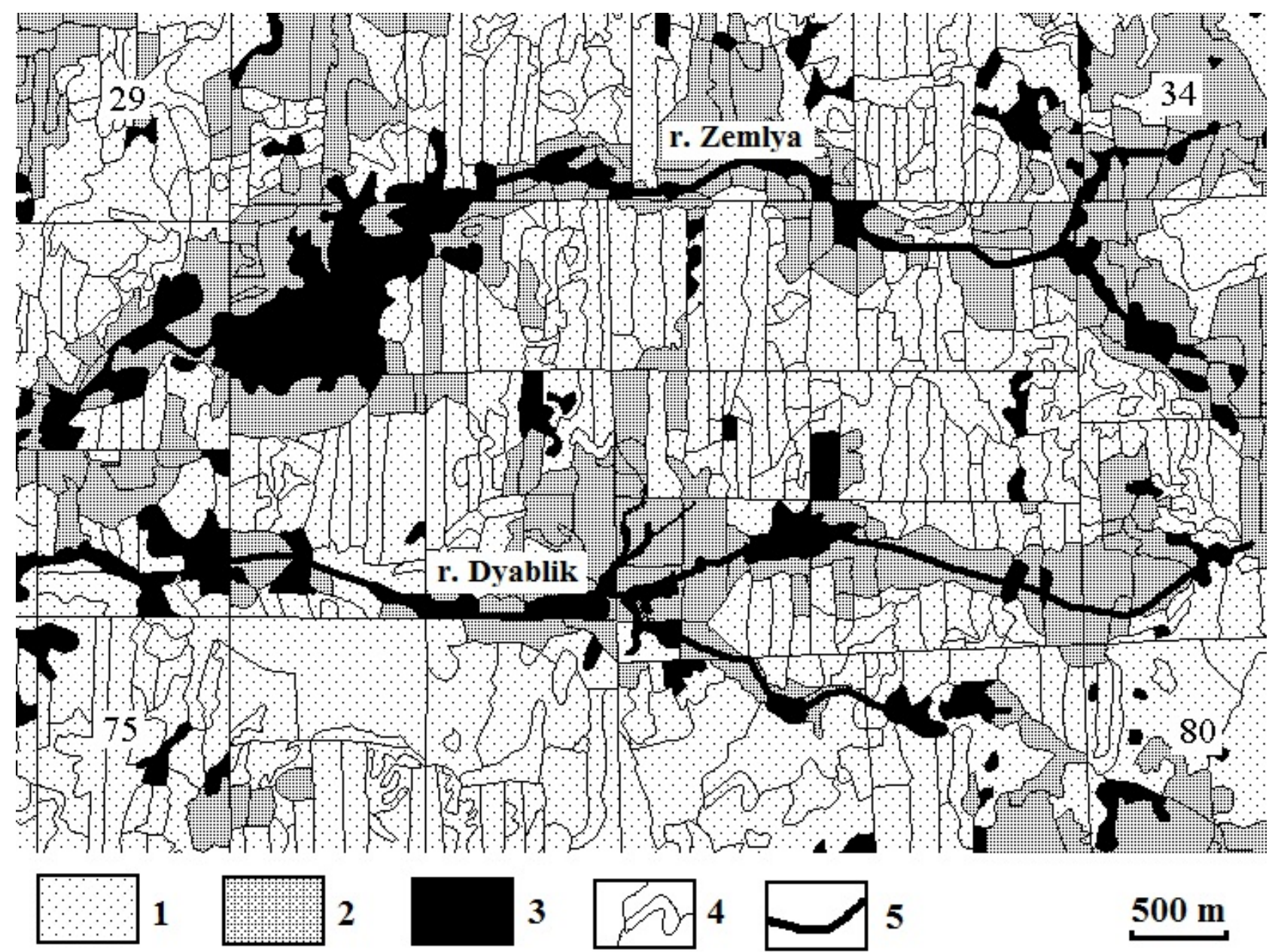

Fig. 6. A fragment of forest vegetation in the interfluve of the small Zemlya and Dyablik rivers.

Nature reserve "Bryansk Forest". Legend: 1 - boreal forest communities of outwash areas;

2 - nemoral forest communities of moraine-outwash areas; 3 - black alder community in floodplain areas

of small rivers and their tributaries; 4 - boundary of forest subcompartments; 5 - the river bed.

The numbers on the map - number of forest taxation quarters 


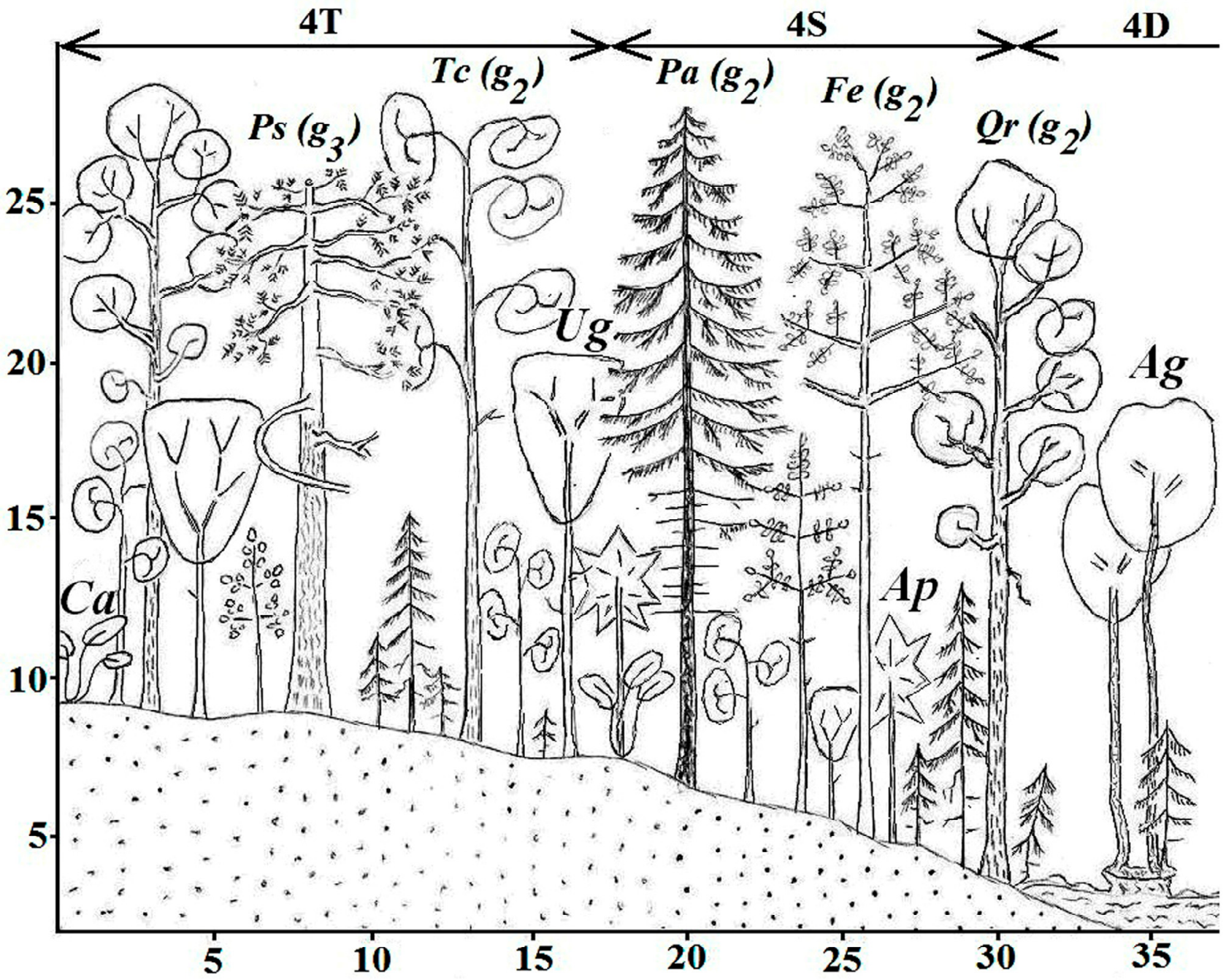

Fig. 7. Vertical structure of forest communities in the fourth stage of succession. Communities: $4 T$ - nemoral polydominant coniferous broad-leaf forest at the top of the ridge, $4 \mathrm{~S}$ - nemoral polydominant spruce broad-leaf forest on a gentle slope of the ridge, $4 \mathrm{D}$ - nettle black alder in depressions. Tree species: $\mathrm{Ag}-\mathrm{Alnus}$ glutinosa,

Ap - Acer platanoides, $\mathrm{Ca}$ - Corylus avellana, Fe - Fraxinus excelsior, $\mathrm{Pa}$ - Picea abies, Ps - Pinus sylvestris, Qr - Quercus robur, Tc - Tilia cordata, Ug - Ulmus glabra. Ontogenic state of trees: $g_{2}$ - mature generative plant, $\mathrm{g}_{3}$ - old generative plant. Horizontal axis - profile length in metres; vertical axis - height above water level in metres

Diverse birds and mammals distribute Padus avium fruits $[44,60]$. Seedlings of this species are detected at a distance of $900 \mathrm{~m}$ from the fructiferous individuals due to endozoochory [57]. Tetrastes bonasia, Sitta europaea, Chloris chloris (Linnaeus) and Sturnus vulgaris Linnaeus eat Ulmus glabra seeds; Fringilla montifringilla Linnaeus, Spinus spinus (Linnaeus), Pyrrhula pyrrhula (Linnaeus), Sitta europaea, Coccothraustes coccothraustes (Linnaeus) and Carpodacus erythrinus (Pallas) eat ash seeds. However, Fraxinus excelsior seeds are pulled apart actively and stores only by Sitta europaea while other birds destroy them [60]. A study of seedlings found that young plants of Fraxinus excelsior appear $250 \mathrm{~m}$ from generative trees, and Ulmus glabra seedling $150 \mathrm{~m}$ from generative trees $[57,61]$. Fraxinus excelsior, Ulmus glabra and Padus avium are megatrophic plants [47, 62]. Suitable soil conditions for these species are created in forests during the later stages of succession. Treefalls form mosaics of pitand-mound microtopography and deadwood variables. Traces of treefalls of different ages and systems of root entrances (rhizotectonics) are formed in the soil cover. Formed by previous generations of trees and treefalls, mosaics and rhizotectonics are used by young trees roots to attain deeper growth [8]. Studies of soil scientists showed that treefall mosaics and rhizotectonics increase the capacity of channel migration of solutes, contribute to the accumulation of soil organic matter, retain moisture for a long time and increase the vertical redistribution of organic matter by mesofauna [63]. All this creates conditions for settling of species with high soil nutritional needs.

Shading and increased soil fertility result in the dominance of nemoral species in the field layer where their projective cover reaches $100 \%$. Species 
richness of herb synusia remains at the same level (see Table 1). According to vegetation data sampling the following species of nemoral plants are present: Adoxa moschatellina L., Alliaria petiolata (Bieb.) Cavara \& Grande, Festuca altissima All., Dentaria bulbifera L., Dryopteris filix-mas (L.) Schott, Galium odoratum (L.) Scop., Glechoma hederacea L., Lathraea squamaria L., Mercurialis perennis L., Neottia nidus-avis (L.) Rich., Paris quadrifolia L., Platanthera bifolia and others.

Phase duration corresponds to time length of $g_{2}$ and $\mathrm{g}_{3}$ stages of Quercus robur (230 to 250 years). After this period the oak falls out of the community due to poor shade tolerance and spruce broadleaved forest without oak is formed.

Succession transformation of pine forests on gentle slopes of ridges (see Fig. 1, S). These ecotopes are characterised by poor, sod-podzolic, gley sandy soils with variable excessive moisture in the early stages of succession. Sometimes the soil is covered with a thin layer of peat (up to $10 \mathrm{~cm}$ ). Ground water does not fall below 20 to $70 \mathrm{~cm}$ in mid-summer.

Four stages are assigned in the development of post-fire communities: boreal polytric pine forest

$\rightarrow$ boreal bilberry-polytric pine forest with spruce undergrowth $\rightarrow$ boreo-nemoral pine forest with admixture of birch (Betula spp.), oak (Quercus robur L.), spruce (Picea abies (L.) Karst) with undergrowth of Tilia cordata Mill., Acer platanoides L. and with an understorey of Corylus avellana L. $\rightarrow$ nemoral polydominant spruce broad-leaved forest.

The first stage: boreal polytric pine forest (see Fig. 2, 1S; Fig. 3, 2). The tree canopy layer consists of $v$ and $g_{l}$ pines. In most cases, pines are 20 to 40 years old. Betula pubescens Ehrh., Salix cinerea L. and Frangula alnus individuals of coppice origin are found sporadically in undergrowth. Polytric moss (Polytrichum commune Hedw.) dominates in the bottom layer (projective cover of $80 \%$ ). Polytric moss cover does not prevent regeneration of Picea abies and $j$ and im individuals meet regularly. Species richness in the field layer is small (see Table 2). Single individuals of boreal species ( $\mathrm{Vac}-$ cinium myrtillus, Trientalis europaea L., Lycopodium annotinum $\mathrm{L}$. and other) and sphagnum-bog species (Carex globularis L., Ledum palustre L. and Vaccinium uliginosum L.) represent the herb and dwarf shrub species.

Table 2

Diversity indices (vascular plants) of forest communities at different stages of succession on gentle slopes of the ridges on outwash terrain

\begin{tabular}{|c|c|c|c|c|}
\hline Diversity indices & 1 stage & 2 stage & 3 stage & 4 stage \\
\hline Number of sample plots & 10 & 10 & 10 & 10 \\
\hline Average number of species per $100 \mathrm{~m}^{2}$ & 13.6 & 15.9 & 33.4 & 33.6 \\
\hline Range of species number per $100 \mathrm{~m}^{2}$ & $11-15$ & $13-19$ & $22-45$ & $25-46$ \\
\hline Total number of species on 10 sample plots & 24 & 33 & 74 & 79 \\
\hline \multicolumn{5}{|c|}{ Number of species (and per cent**) of ecological-coenotic species group on 10 sample plots } \\
\hline The boreal forest group & $10(41.7)$ & $13(39.4)$ & $15(20.3)$ & $15(19.0)$ \\
\hline The piny group (edge boreal group) & $4(16.7)$ & $5(15.2)$ & $9(12.2)$ & $3(3.8)$ \\
\hline The nemoral forest group & $2(8.3)$ & $4(12.1)$ & $27(36.5)$ & $47(59.4)$ \\
\hline The nemoral edge group & - & - & $2(2.7)$ & $1(1.3)$ \\
\hline The dry meadow group & - & $3(9.1)$ & $12(16.2)$ & - \\
\hline The wet meadow group & - & - & $5(6.8)$ & $1(1.3)$ \\
\hline The nitrophilous forest group & $1(4.2)$ & $1(3.0)$ & - & $9(11.4)$ \\
\hline The nitrophilous edge group & - & - & $1(1.3)$ & $1(1.3)$ \\
\hline The water-marsh group & $2(8.3)$ & $2(6.0)$ & $3(4.0)$ & $2(2.5)$ \\
\hline The oligotrophic group & $5(20.8)$ & $5(15.2)$ & - & - \\
\hline
\end{tabular}

Footnote. $* *$ - number of species on the 10 sample plots (area of each sample plot $100 \mathrm{~m}^{2}$ ) is taken as $100 \%$.

Stage duration is determined by the time necessary for the formation of dense Vaccinium myrtillus cover. Vegetative sprouting bilberry can form dense cover over 15 to 20 years.

The second stage: boreal bilberry-polytric pine forest with spruce undergrowth (Fig. 5, 2S; Fig. 3, 6; Fig. 4). The tree canopy layer consists of $g_{1}$ and $g_{2}$ pines with ages of 40 to 60 years. Virginile spruce individuals and immature oak individuals appear in the undergrowth. Dominance in ground vegetation shifts from Polytrichum commune to Vaccinium myrtillus under the forest canopy and to Molinia caerulea (L.) Moench in light sites. It forms dense cover. Species richness of dwarf shrubs and herb synusiae is small and is still represented by species of boreal and sphagnum-bog groups (see Table 2). 
Stage duration is determined by the time needed for spruce and oak undergrowth to form a dense shrub layer canopy and is equal to the length of their $v$ ontogenetic stage ( 40 to 50 years).

The third stage: boreo-nemoral pine forest with admixture of birch (Betula spp.), oak (Quercus robur), spruce (Picea abies), with undergrowth of Tilia cordata, Acer platanoides and with an understorey of Corylus avellana (see Fig. 4, 3TS). The tree canopy layer consists of $g_{2}$ pines and birches as well as $g_{l}$ spruces and oaks. Pines age from 60 to 120 years. Undergrowth of Tilia cordata, Acer platanoides, Malus sylvestris, Populus tremula and shrubs, including Corylus avellana, Euonymus verrucosa and Viburnum opulus L. appear in the understorey layer. The degree of understorey layer coverage is $80 \%$ and is defined by the following changes in the ground vegetation: (1) synusia of ground bryophytes becomes fragmented; (2) dense cover of Vaccinium myrtillus and Molinia caerulea is destroyed; (3) species richness is doubled in comparison with the previous stage and (4) nemoral and boreal species groups codominate (see Table 2).

Stage duration is determined by the time needed for spruce and oak to grow into a tree canopy layer and is equal to the length of their $g_{l}$ ontogenetic stage (30 to 50 years). Communities on the tops of ridges and on slopes are similar to each other after the third stage. A similar species composition of tree and shrub synusiae and similar ratios in coverage of species groups of different eco-cenotic groups testifies to this.

The fourth stage: nemoral polydominant spruce broad-leaved forest (see Fig. 3, IV; Fig. 4, 4TS-1; Fig. 7, 4S). The tree canopy layer consists of $g_{3}$ pine and birch, $g_{2}$ spruce and oak, as well as $g_{1}$ linden and maple. Fraxinus excelsior, Ulmus glabra and Swida sanguinea (L.) Opiz. appear in the understorey layer. Seeds of Swida sanguinea are spread by different species of birds: Tetrastes bonasia (Linnaeus), Bombycilla garrulus (Linnaeus), Ficedula spp., Phoenicurus spp., Turdus spp., Coccothraustes coccothraustes (Linnaeus) and Pyrrhula pyrrhula (Linnaeus) [60].

Nemoral species dominate the ground vegetation. Species richness is highest of all stages (see Table 2) due to the following circumstances: (1) the enhanced community, which is attractive to birds that carry the seeds (there are also additional places to hide and nest in the form of treefall gaps with undergrowth, hollows in old tree trunks etc.); (2) acorns of fruiting oak attract wild boars, which nuzzle soil and create favourable substrate for the growth of short-lived plants (Impatiens nolitangere L., Moehringia trinervia (L.) Clairv, etc.);
(3) an increase in the volume of deadwood where Solanum dulcamara L., Athyrium filix-femina (L.) Roth and Dryopteris filix-mas grow and (4) anemochorous plants with small diasporas appear in the herb cover: Botrychium virginianum (L.) Sw, Huperzia selago (L.) Bernh. ex Schrank \& C. Mart., Gymnocarpium dryopteris (L.) Newm., Dryopteris expansa (C. Presl) Fraser-Jenkins \& Jermy, Listera ovata (L.) R. Br., Platanthera bifolia and Corallorrhiza trifida Chatel.

Stage duration is determined by the duration of $g_{2}$ and $g_{3}$ stages of oak and spruce (230 to 250 years). After this period oak will completely fall out of the community.

\section{Conclusion}

Pine forests in outwash areas form two successional series developed under different ecotopical conditions. The following successional series occurs at the tops of ridges: boreal green moss pine forest $\rightarrow$ boreal green moss - dwarf shrub forests $\rightarrow$ boreo-nemoral pine forest with admixture of birch, oak, spruce $\rightarrow$ nemoral polydominant spruce broad-leaved forest. The other successional series is formed on gentle ridge slopes: boreal polytric pine forest $\rightarrow$ boreal bilberry-polytric pine forest $\rightarrow$ boreo-nemoral pine forest with admixture of birch, oak, spruce $\rightarrow$ nemoral polydominant spruce broad-leaved forest. These series show that elevated and sloping sites of outwash areas are characterised by a convergent path of community development in which two different phytocenoses form one final community variant .

The analysis of the successional changes of the boreal pine forests showed that in different ecotopical conditions (top and slopes of ridges) the zonal community type was formed gradually and was represented by spruce broad-leaved forests with nemoral species composition. It demonstrates that boreal pine forests are secondary variants of zonal communities. The boreal pine forests were formed on the sites of spruce broad-leaved forest as a result of human impact such as fires, felling and forest plantations over many centuries.

Successional changes are based on seed dispersal, especially by animals. They provide plant diasporas drift to pine forests from refugia of spruce broad-leaved forests, which have been preserved along the sides of small rivers and stream valleys. The number of species and abundance of nesting bird populations increased two or more fold during the process of spruce broad-leaved forest formation and with increasing community mosaic complexity [64]. Additionally, the number of ungulates in the spruce broad-leaved forest is much higher than in pine forest [65]. All this contributes to the expan- 
sion of animal species that act as distributors of seeds and activate drift of plant diasporas from the surrounding areas during succession.

In early stages of succession ecotopes play the leading role in the spatial organisation of cenoses: green moss pine forests are formed on relatively dry sites on the top of ridges, while polytric pine forests are formed in relatively moist slope sites. Ecotopic mosaics are complicated by vegetation patterns caused by animals (carriers of seeds) in the intermediate stages of succession. Endo- and sin-zoochoric plant species appear in the community. For example, Vaccinium vitis-idaea, Convallaria majalis, Sorbus aucuparia and Quercus robur often take root at the top of ridges, while Vaccinium myrtillus, Frangula alnus and Picea abies take root on the slopes. Mosaics created by trees are superimposed on a mosaic resulting from ecotopes and animals in the final stages of succession: treefall gaps appear after the death of old trees and gaps are overgrown with undergrowth. As a result, a community with a number of asynchronously developing gaps is formed in the place of homogeneous pine forest.

Three groups of species in tree and shrub synusiae are allocated based on features of their appearance in the successional series. The first group includes Quercus robur, Picea abies, Betula pendula, B. pubescens, Frangula alnus and Sorbus aucuparia. These species are introduced into the pine forests at the early stages of succession. Representatives of this group are able first to take root in poor sandy substrate due to their low soil nutrient demand [62]. The second group includes mesotrophic species: Acer platanoides, Tilia cordata, Populus tremula, Malus sylvestris, Corylus avellana, Euonymus verrucosa. These species are being actively moved into forest communities after relatively oligotrophic species (Quercus robur, Picea abies, Betula pendula) reach the tree canopy layer and form a suitable environment for their colonisation. The third group includes megatrophic species: Ulmus glabra, Fraxinus excelsior and Swida sanguinea. Often these species appear in the communities during the final stages of succession when a humus-accumulation horizon is formed in the soil cover with treefall mosaics with rhizotectonics is formed, which are necessary for the growth of young tree roots.

The gradual invasion of tree species to the forest community formed the polydominant coniferous broad-leaved forest. However, the existence of Quercus robur and Pinus sylvestris is limited to the first generation in these communities because undergrowth of these species is not able to grow due to poor shade tolerance under dark forest canopy $[3,66,67]$. As a result, spruce-broadleaved forests without pine and oak will represent the final stages of forest succession in outwash areas (see Fig. 4, 4TS-2).

The coverage of species of different ecologicalcoenotic groups changes in the synusiae of herbs and dwarf shrubs during succession. Boreal species dominate at the early stages of succession; boreal, dry meadow and nemoral species groups codominate at the intermediate stages and nemoral species dominate at the final stages. Maximum species richness of herb synusia is typical during the third and fourth stages of succession. Species of boreal, dry meadow and nemoral groups are represented in significant number during the third stage. This is due to the fact that a dense layer of undergrowth of late-successional tree species, which displaces the light-loving meadow and boreal species, has not yet formed at this stage. High species richness at the fourth stage is determined by the increased frequency of rare plant species in Nerussa-Desna Polesie.

Fires provoked by man limit the invasion of plants and delay the recovery processes for a long time. Elongated and shortened cycles of vegetation development are formed. Shortened cycles occur when fire affects communities at the early stages of succession and elongated cycles occur if fire destroys cenoses at the final stages of succession. Additionally, not all pine forests in outwash areas are transformed into spruce broad-leaved forests with a full set of plant species during succession. This happens if community does not receive a sufficient number of diasporas of some species from the surrounding areas. In this case, the final stage of succession will be a diasporic sub-climax.

\section{References}

1. Smirnova, O. V. Potential ecosystem cover - a new approach to the conservation biology / O. V. Smirnova, N. A. Toropova // Russian Journal of Ecosystem Ecology. - 2016. - Vol. 1 (1). - URL: http://rjee.ru/rjee-1-12016-1

2. Восточноевропейские широколиственные леса / под ред. О. В. Смирновой. - М. : Наука, 1994. - 364 с.

3. Восточноевропейские леса: история в голоцене и современность / отв. ред. О. В. Смирнова. - М. : Наука, 2004. - Кн. 2. -575 c.

4. Реконструкция истории биоценотического покрова Восточной Европы и проблема поддержания биологического разнообразия / О. В. Смирнова, С. А. Турубанова, М. В. Бобровский, В. Н. Коротков, Л. Г. Ханина // Успехи современной биологии. - 2001. - № 2. - С. 144-159. 
5. Смирнова, О. В. Представление о потенциальном и восстановленном растительном покрове лесного пояса Восточной Европы / О. В. Смирнова, Е. Ю. Бакун, С. А. Турубанова // Лесоведение. - 2006. - № 1. С. 22-33.

6. Смирнова, О. В. Модельная реконструкция восстановленного лесного покрова таежных лесов / О. В. Смирнова, Д. Л. Луговая, Т. С. Проказина // Успехи современной биологии. - 2013. - Т. 133, № 2. C. $164-177$.

7. Смирнова, О. В. Формирование и развитие восточноевропейских широколиственных лесов в голоцене / О. В. Смирнова, С. А. Турубанова // Бюллетень Московского общества испытателей природы. Отдел биологический. - 2003. - Т. 108, № 2. - С. 32-40.

8. Бобровский, М. В. Лесные почвы Европейской России: биотические и антропогенные факторы формирования / М. В. Бобровский. - М. : Товарищество научных изданий КМК, 2010. - 359 с.

9. Коротков, В. Н. Демутационные процессы в островных лесных массивах (на примере ГИЗЛ «Горки Ленинские» и Каневского заповедника) : автореф. дис. ... канд. биол. наук / Коротков В. Н. - М., 1992. - 16 с.

10. Коротков, В. Н. Флористическое разнообразие лесов ГИЗЛ «Горки Ленинские» в связи с историей хозяйственного использования территории / В. Н. Коротков // Сохранение и восстановление природнокультурных комплексов Подмосковья. - М. : Улисс, 1995. - С. 56-62.

11. Коротков, В. Н. Природно-исторический заповедник-леспаркхоз «Горки» / В. Н. Коротков // Оценка и сохранение биоразнообразия лесного покрова в заповедниках Европейской России / под ред. Л. Б. Заугольновой. - М. : Научный мир, 2000. - С. 46-72.

12. Бобровский, М. В. Козельские засеки (эколого-исторический очерк) / М. В. Бобровский. - Калуга : Изд-во Н. Бочкаревой, 2002. - 92 с.

13. Бобровский, М. В. История лесов заповедника «Калужские засеки» / М. В. Бобровский. - Калуга : Гос. природный заповедник «Калужские засеки», 2007. - 61 с.

14. Леонова, Н. А. Основные этапы преобразования растительного покрова западных склонов Приволжской возвышенности в голоцене / Н. А. Леонова // Современные концепции экологии биосистем и их роль в решении проблем сохранения природы и природопользования. - Пенза : Изд-во ПГУ, 2016. - С. 315-318.

15. Беляева, Т. Ю. История природопользования на территории Неруссо-Деснянского полесья. Заповедник «Брянский лес» / Т. Ю. Беляева // Сукцессионные процессы в заповедниках России и проблемы сохранения биологического разнообразия / под ред. О. В. Смирновой, Е. С. Шапошникова. - СПб. : РБО, 1999. C. $152-160$.

16. Евстигнеев, О. И. Деградация биогеоценотического покрова Среднего Подесенья в голоцене / О. И. Евстигнеев // Принципы и способы сохранения биоразнообразия. - Йошкар-Ола, Пущино : Марийский гос. ун-т, 2008. - С. 142-144.

17. Евстигнеев, О. И. Неруссо-Деснянское полесье: история природопользования / О. И. Евстигнеев. - Брянск : Десяточка, 2009. - 139 с.

18. Евстигнеев, О. И. Механизмы поддержания биологического разнообразия лесных биогеоценозов : дис. ... д-ра биол. наук / О. И. Евстигнеев. - Н. Новгород, 2010. - 513 с.

19. Растительность европейской части СССР / под ред. С. А. Грибовой, Т. И. Исаченко, Е. М. Лавренко. - Л. : Наука, 1980. - 431 с.

20. Евстигнеев, О. И. Сукцессионные процессы в растительном покрове третьей супесчаной террасы НеруссоДеснянского полесья (на примере заповедника «Брянский лес» и окружающих территорий) / О. И. Евстигнеев // Восточноевропейские леса: история в голоцене и современность / отв. ред. О. В. Смирнова. - М. : Наука, 2004. - Кн. 2. - С. 266-278.

21. Географический энциклопедический словарь. Понятия и термины. - М. : Сов. энцикл., 1988. - 432 с.

22. Морозова, О. В. Леса заповедника «Брянский лес» и Неруссо-Деснянского полесья (синтаксономическая характеристика) / О. В. Морозова. - Брянск : Заповедник «Брянский лес», 1999. - 98 с.

23. Тихонов, А. С. Брянский лесной массив / А. С. Тихонов. - Брянск : Читай-город, 2001. - 312 с.

24. Алехин, В. В. Растительность СССР / В. В. Алехин. - М. : Сов. наука, 1951. - 511 с.

25. Вальтер, Г. Растительность земного шара. Эколого-физиологическая характеристика. Леса умеренной зоны / Г. Вальтер. - М. : Прогресс, 1974. - 424 с.

26. Евстигнеев, О. И. Ландшафтная структура и растительность Неруссо-Деснянского полесья / О. И. Евстигнеев // Оценка и сохранение биоразнообразия лесного покрова в заповедниках Европейской России. - М. : Научный мир, 2000. - С. 128-135.

27. Миркин, Б. М. Словарь понятий и терминов современной фитоценологии / Б. М. Миркин, Г. С. Розенберг, Л. Г. Наумова. - М. : Наука, 1989. - 223 с.

28. Оценка и сохранение биоразнообразия лесного покрова в заповедниках Европейской России / под ред. Л. Б. Заугольновой. - М. : Научный мир, 2000. - 196 с.

29. Ниценко, А. А. Об изучении экологической структуры растительного покрова / А. А. Ниценко // Ботанический журнал. - 1969. - Т. 54, № 7. - С. 1002-1014.

30. Смирнова, О.В.Эколого-ценотические группы в растительном покрове лесного пояса Восточной Европы / О. В. Смирнова, Л. Г. Ханина, В. Э. Смирнов // Восточноевропейские леса: история в голоцене и современность. - М. : Наука, 2004. - Кн. 1. - С. 165-175. 
31. Смирнов, В. Э. Обоснование системы эколого-ценотических групп видов растений на основе экологических шкал, геоботанических описаний и статистического анализа / В. Э. Смирнов, Л. Г. Ханина, М. В. Бобровский // Бюллетень Московского общества испытателей природы. Отдел биологический. 2006. - Т. 111, № 1. - С. 36-47.

32. Диагнозы и ключи возрастных состояний лесных растений. Деревья и кустарники / под ред. О. В. Смирновой. - М. : Прометей, 1989. - 102 с.

33. Романовский, А. М. Поливариантность онтогенеза Picea abies (Pinaceae) в Брянском полесье / А. М. Романовский // Ботанический журнал. - 2001. - № 8. - С. 72-85.

34. Евстигнеев, О. И. Поливариантность сосны обыкновенной в Брянском полесье / О. И. Евстигнеев // Лесоведение. - 2014. - № 2. - С. 69-77.

35. Evstigneev, O. I. Ontogenetic stages of trees: an overview / O. I. Evstigneev, V. N. Korotkov // Russian Journal of Ecosystem Ecology. - 2016. - Vol. 1 (2). - P. 1-36. - URL: http://rjee.ru/rjee-1-1-2016-2/

36. Популяционная организация растительного покрова лесных территорий (на примере широколиственных лесов Европейской части СССР) / О. В. Смирнова, А. А. Чистякова, Р. В. Попадюк, О. И. Евстигнеев, В. Н. Коротков, М. В. Митрофанова, Е. В. Пономаренко. - Пущино : ОНТИ Научный центр биологических исследований АН СССР, 1990. - 92 с.

37. Популяционная диагностика и прогнозы развития заповедных лесных массивов (на примере Каневского заповедника) / О. В. Смирнова, Р. Р. Возняк, О. И. Евстигнеев, В. Н. Коротков, Н. Я. Носач, Р. В. Попадюк, В. К. Самойленко, Н. А. Торопова // Ботанический журнал. - 1991. - Т. 76 (6). - С. 860-871.

38. Стоянів, Ю. До фльори Акулицьких лїсїв Брянщини / Ю. Стоянїв // Укр. бот. журн. - 1921. - № 1. C. $10-22$.

39. Военно-статистическое обозрение Российской империи, издаваемое по Величайшему повелению при 1-м отделении Департамента Генерального штаба. Орловская губерния. - СПб. : 1-е Отделение Деп. Ген. штаба, 1853. - Т. VI, ч. 5. - 158 с.

40. Цветков, М. А. Изменение лесистости Европейской России с конца XVII столетия по 1914 г. / М. А. Цветков. - М. : АН СССР, 1957. - 213 с.

41. Санников, С. Н. Экология и география естественного возобновления сосны обыкновенной / С. Н. Санников. - М. : Наука, 1992. - 262 с.

42. Евстигнеев, О. И. Сукцессии сосновых лесов зандровой местности в Неруссо-Деснянском полесье / О. И. Евстигнеев, В. Н. Коротков // Бюллетень Брянского отделения Русского ботанического общества. 2013. - № 1 (1). - C. 31-41.

43. Абатуров, А. М. Полесья Русской равнины в связи с проблемой их освоения / А. М. Абатуров. - М. : Мысль, 1968. - 246 с.

44. Левина, Р. Е. Способы распространения плодов и семян / Р. Е. Левина. - М. : Изд-во МГУ, 1957. - 360 с.

45. Евстигнеев, О. И. Зоохория и дальность разноса семян в хвойно-широколиственных лесах Восточной Европы / О. И. Евстигнеев, П. В. Воеводин, В. Н. Коротков, И. А. Мурашев // Успехи современной биологии. 2013. - T. 133 (4). - С. 392-400.

46. Серебряков, И. Г. Экологическая морфология растений. Жизненные формы покрытосеменных и хвойных растений / И. Г. Серебряков. - М. : Высш. шк., 1962. 378 с.

47. Цыганов, Д. Н. Фитоиндикация экологических режимов в подзоне хвойно-широколиственных лесов / Д. Н. Цыганов. - М. : Наука, 1983. - 198 с.

48. Мертц, П. А. Олени Воронежского заповедника в окрестности лесхоза / П. А. Мертц // Бюллетень Московского общества испытателей природы. Отдел биологический. - 1951. - Т. 56, № 5. - С. 31-44.

49. Кириков, С. В. Птицы и млекопитающие в условиях ландшафтов южной оконечности Урала / С. В. Кириков. - М. : Изд-во АН СССР, 1952. - 412 с.

50. Новиков, Г. А. Еловые леса как среда обитания и роль в их жизни млекопитающих и птиц / Г. А. Новиков // Роль животных в жизни леса. - М. : Изд-во МГУ, 1956. - С. 6-165.

51. Семенов-Тян-Шанский, О. И. Экология тетеревиных птиц / О. И. Семенов-Тян-Шанский // Труды Лапландского государственного заповедника. - М. : Главное управление охотничьего хозяйства и заповедников при Совете Министров РСФСР, 1959. - Вып. 5. - 319 с.

52. Формозов, А. Н. Звери, птицы и их взаимоотношения со средой обитания / А. Н. Формозов. - М. : Наука, 1976. - 309 c.

53. Аверин, Ю. В. Птицы Молдавии / Ю. В. Аверин, И. М. Ганя, Г. А. Успенский. - Кишинёв : Штиинца, 1971. $236 \mathrm{c.}$

54. Калецкий, А. А. Растительные корма лося в летне-осенний период / А. А. Калецкий // Биология и промысел лося. - М. : Россельхозиздат, 1965. - С. 113-135.

55. Самарский, С. Л. Материалы по питанию лисицы, барсука и каменной куницы в условиях Среднего Днепра / С. Л. Самарский, Н. Я. Бойко // Изучение ресурсов наземных позвоночных фауны Украины. - Киев : Наук. думка, 1969. - С. 99-101.

56. Медведи: бурый медведь, белый медведь, гималайский медведь. Размещение запасов, экология, использование и охрана. - М. : Наука, 1993. - 519 с.

57. Евстигнеев, О. И. Оценка дальности приживания подроста деревьев и кустарников от широколиственного леса / О. И. Евстигнеев, П. В. Воеводин // Современные проблемы популяционной экологии, геоботаники, систематики и флористики. - Кострома : КГУ им. Н. А. Некрасова, 2011. - Т. 2. - С. 11-13. 
58. Дунин, В. Ф. Изучение зимнего питания лося методом тропления / В. Ф. Дунин // Заповедники Белоруссии. Минск : Ураджай, 1981. - Вып. 5. - С. 74-79.

59. Казьмин, В. Д. Зимнее питание, кормовые ресурсы и трофическое воздействие зубра на лесные фитоценозы Центрального Кавказа / В. Д. Казьмин, К. А. Смирнов // Бюллетень Московского общества испытателей природы. Отдел биологический. - 1992. - Т. 97, № 2. - С. 26-35.

60. Нечаев, В. А. Птицы - потребители и распространители плодов и семян древесных растений в Приморском крае / В. А. Нечаев // Бюллетень Московского общества испытателей природы. Отдел биологический. 2001. - T. 106, № 2. - С. 14-21.

61. Евстигнеев, О. И. Анемохория и дальность рассеивания семян деревьев восточноевропейских лесов / О. И. Евстигнеев, И. А. Мурашев, В. Н. Коротков // Лесоведение. - 2016. - № 5. - С. 384-392.

62. Погребняк, П. С. Общее лесоводство / П. С. Погребняк. - М. : Колос, 1968. - 440 с.

63. Ремезов, Н. П. Лесное почвоведение / Н. П. Ремезов, П. С. Погребняк. - М. : Лесная промышленность, 1965. $-324 \mathrm{c}$.

64. Косенко, С. М. Структура и организация лесных сообществ гнездящихся птиц заповедника «Брянский лес»/ С. М. Косенко, Е. Ю. Кайгородова // Бюллетень Московского общества испытателей природы. Отдел биологический. -2000 . - Т. 105, № 1. - С. 21-26.

65. Евстигнеев, О. И. Биогеоценотический покров Неруссо-Деснянского Полесья: механизмы поддержания биологического разнообразия / О. И. Евстигнеев, В. Н. Коротков, К. В. Беляков, Т. Ю. Браславская, А. М. Романовский, Г. Е. Рубашко, Е. П. Сарычева, Ю. П. Федотов ; под ред. О. В. Смирновой. - Брянск : Заповедник «Брянский лес», 1999. - 176 с.

66. Евстигнеев, О. И. Отношение лиственных деревьев к свету и водообеспеченности в связи со структурой леса / О. И. Евстигнеев // Лесоведение. - 1996. - № 6. - С. 26-35.

67. Евстигнеев, О. И. Световой минимум подроста деревьев хвойно-широколиственного леса / О. И. Евстигнеев // Структурно-функциональная организация и динамика растительного покрова. - Самара : Изд-во Поволж. соц.-гум. акад., 2012. - С. 181-184.

\section{References}

1. Smirnova O. V., Toropova N. A. Russian Journal of Ecosystem Ecology. 2016, vol. 1 (1). Available at: http://rjee.ru/rjee-1-1-2016-1

2. Vostochnoevropeyskie shirokolistvennye lesa [East European broad-leaved forests]. Ed. by O. V. Smirnova. Moscow: Nauka, 1994, 364 p.

3. Vostochnoevropeyskie lesa: istoriya v golotsene i sovremennost' [East European forests: history in Holocene and modern times]. Ed. by O. V. Smirnova. Moscow: Nauka, 2004, bk. 2, 575 p.

4. Smirnova O. V., Turubanova S. A., Bobrovskiy M. V., Korotkov V. N., Khanina L. G. Uspekhi sovremennoy biologii [Achievements of modern biology]. 2001, no. 2, pp. 144-159.

5. Smirnova O. V., Bakun E. Yu., Turubanova S. A. Lesovedenie [Forest science]. 2006, no. 1, pp. $22-33$.

6. Smirnova O. V., Lugovaya D. L., Prokazina T. S. Uspekhi sovremennoy biologii [Achievements of modern biology]. 2013, vol. 133, no. 2, pp. 164-177.

7. Smirnova O. V., Turubanova S. A. Byulleten' Moskovskogo obshchestva ispytateley prirody. Otdel biologicheskiy [Moscow Society of Naturalists News. Biological series]. 2003, vol. 108, no. 2, pp. 32-40.

8. Bobrovskiy M. V. Lesnye pochvy Evropeyskoy Rossii: bioticheskie i antropogennye faktory formirovaniya [Forest soils of European Russia: biotic and anthropogenic factors of forming]. Moscow: Tovarishchestvo nauchnykh izdaniy KMK, 2010, 359 p.

9. Korotkov V. N. Demutatsionnye protsessy v ostrovnykh lesnykh massivakh (na primere GIZL "Gorki Le-ninskie» $i$ Kanevskogo zapovednika): avtoref. dis. kand. biol. nauk [Demutation processes in insular forest areas (on the example of Gorki Leninskiye and Kanevsky Natural Reserves): abstract of a thesis of Candidate of Biological Sciences]. Moscow, 1992, 16 p.

10. Korotkov V. N. Sokhranenie i vosstanovlenie prirodno-kul'turnykh kompleksov Podmoskov'ya [Preservation and restoration of natural and cultural complexes in Moscow adjacent aras]. Moscow: Uliss, 1995, pp. 56-62.

11. Korotkov V. N. Otsenka i sokhranenie bioraznoobraziya lesnogo pokrova v zapovednikakh Evropeyskoy Rossii [Evaluation and preservation of biological diversity of forest cover in European Russia natural reserves]. Moscow: Nauchnyy mir, 2000, pp. 46-72.

12. Bobrovskiy M. V. Kozel'skie zaseki (ekologo-istoricheskiy ocherk) [Kozelsky abatis (ecological and historical essay)]. Kaluga: Izd-vo N. Bochkarevoy, 2002, 92 p.

13. Bobrovskiy M. V. Istoriya lesov zapovednika "Kaluzhskie zaseki» [History of forests in "Kozelsky abates" natural reserve]. Kaluga: Gos. prirodnyy zapovednik «Kaluzhskie zaseki», 2007, 61 p.

14. Leonova N. A. Sovremennye kontseptsii ekologii biosistem i ikh rol'v reshenii problem sokhraneniya prirody $i$ prirodopol'zovaniya [Modern concepts of biosystem ecology and their role in solving problems of preserving nature and management of natural resources]. Penza: Izd-vo PGU, 2016, pp. 315-318.

15. Belyaeva T. Yu. Suktsessionnye protsessy v zapovednikakh Rossii i problemy sokhraneniya biologicheskogo raznoobraziya [Successional processes in Russian natural reserves and problems of preserving biological diversity]. Saint-Petersburg: RBO, 1999, pp. 152-160. 
16. Evstigneev O. I. Printsipy i sposoby sokhraneniya bioraznoobraziya [Methods and ways of preserving biological diversity]. Yoshkar-Ola, Pushchino: Mariyskiy gos. un-t, 2008, pp. 142-144.

17. Evstigneev O. I. Nerusso-Desnyanskoe poles'e: istoriya prirodopol'zovaniya [Nerussa-Desna polesie: history of natural resources management]. Bryansk: Desyatochka, 2009, 139 p.

18. Evstigneev O. I. Mekhanizmy podderzhaniya biologicheskogo raznoobraziya lesnykh biogeotsenozov: dis. d-ra biol. nauk [Mechanisms of maintaining biological diversity of forest biogeocoenosis: thesis of Doctor of Biological Sciences]. Nizhniy Novgorod, 2010, 513 p.

19. Rastitel'nost' evropeyskoy chasti SSSR [Vegetation of European part of the USSR]. Eds. S. A. Gribova, T. I. Isachenko, E. M. Lavrenko. Leningrad: Nauka, 1980, 431 p.

20. Evstigneev O. I. Vostochnoevropeyskie lesa: istoriya v golotsene i sovremennost' [East European forests: history in Holocene and modern times]. Moscow: Nauka, 2004, bk. 2, pp. 266-278.

21. Geograficheskiy entsiklopedicheskiy slovar'. Ponyatiya i terminy [Geographical encyclopedia: definitions and terms ]. Moscow: Sov. entsikl., 1988, 432 p.

22. Morozova O. V. Lesa zapovednika «Bryanskiy les» i Nerusso-Desnyanskogo poles'ya (sintaksonomicheskaya kharakteristika) [Forests of "Bryansk Les" natural reserve and Nerussa-Desna polesie (syntaxonomic characteristic)]. Bryansk: Zapovednik «Bryanskiy les», 1999, 98 p.

23. Tikhonov A. S. Bryanskiy lesnoy massiv [Bryansk forest area]. Bryansk: Chitay-gorod, 2001, 312 p.

24. Alekhin V. V. Rastitel'nost' SSSR [Vegetation of the USSR]. Moscow: Sov. nauka, 1951, $511 \mathrm{p}$.

25. Val'ter G. Rastitel'nost' zemnogo shara. Ekologo-fiziologicheskaya kharakteristika. Lesa umerennoy zony [Vegetation of the globe. Ecological and physiological characteristic. Forests of the temperate zone]. Moscow: Progress, 1974,424 p.

26. Evstigneev O. I. Otsenka i sokhranenie bioraznoobraziya lesnogo pokrova v zapovednikakh Evropeyskoy Rossii [Evaluation and preservation of biological diversity of forest cover in European Russia natural reserves]. Moscow: Nauchnyy mir, 2000, pp. 128-135.

27. Mirkin B. M., Rozenberg G. S., Naumova L. G. Slovar' ponyatiy i terminov sovremennoy fitotsenologii [Dictionary of terms and definitions of modern phytocenology]. Moscow: Nauka, 1989, 223 p.

28. Otsenka i sokhranenie bioraznoobraziya lesnogo pokrova v zapovednikakh Evropeyskoy Rossii [Evaluation and preservation of biological diversity of forest cover in European Russia natural reserves]. Ed. by L. B. Zaugol'nova. Moscow: Nauchnyy mir, 2000, 196 p.

29. Nitsenko A. A. Botanicheskiy zhurnal [Botanical journal]. 1969, vol. 54, no. 7, pp. 1002-1014.

30. Smirnova O. V., Khanina L. G., Smirnov V. E. Vostochnoevropeyskie lesa: istoriya v golotsene i sovremennost' [East European forests: history in Holocene and modern times]. Moscow: Nauka, 2004, bk. 1, pp. $165-175$.

31. Smirnov V. E., Khanina L. G., Bobrovskiy M. V. Byulleten' Moskovskogo obshchestva ispytateley prirody. Otdel biologicheskiy [Moscow Society of Naturalists News. Biological series]. 2006, vol. 111, no. 1, pp. 36-47.

32. Diagnozy $i$ klyuchi vozrastnykh sostoyaniy lesnykh rasteniy. Derev'ya i kustarniki [Diagnosis and clues of age conditions of forest plants: trees and shrubs]. Ed. by O. V. Smirnova. Moscow: Prometey, 1989, $102 \mathrm{p}$.

33. Romanovskiy A. M. Botanicheskiy zhurnal [Botanical journal]. 2001, no. 8, pp. 72-85.

34. Evstigneev O. I. Lesovedenie [Forest science]. 2014, no. 2, pp. 69-77.

35. Evstigneev O. I., Korotkov V. N. Russian Journal of Ecosystem Ecology. 2016, vol. 1 (2), pp. 1-36. Available at: http://rjee.ru/rjee-1-1-2016-2/

36. Smirnova O. V., Chistyakova A. A., Popadyuk R. V., Evstigneev O. I., Korotkov V. N., Mitrofanova M. V., Ponomarenko E. V. Populyatsionnaya organizatsiya rastitel'nogo pokrova lesnykh territoriy (na primere shirokolistvennykh lesov Evropeyskoy chasti SSSR) [Population organization of vegetation cover of forest areas (on the example of broad-leaved forests of the USSR European part]. Pushchino: ONTI Nauchnyy tsentr biologicheskikh issledovaniy AN SSSR, 1990, 92 p.

37. Smirnova O. V., Voznyak R. R., Evstigneev O. I., Korotkov V. N., Nosach N. Ya., Popadyuk R. V., Samoylenko V. K., Toropova N. A. Botanicheskiy zhurnal [Botanical journal]. 1991, vol. 76 (6), pp. 860-871.

38. Stoyaniv Yu. Ukr. bot. zhurn. [Ukranian botanical journal]. 1921, no. 1, pp. 10-22.

39. Voenno-statisticheskoe obozrenie Rossiyskoy imperii, izdavaemoe po Velichayshemu poveleniyu pri 1-m otdelenii Departamenta General'nogo shtaba. Orlovskaya guberniya [Military and statistic review of the Russian Empire issued by the supreme command at the first department of the General Staff]. Saint-Petersburg: 1-e Otdelenie Dep. Gen. shtaba, 1853, vol. VI, part 5, 158 p.

40. Tsvetkov M. A. Izmenenie lesistosti Evropeyskoy Rossii s kontsa XVII stoletiya po 1914 g. [Changes in forest cover of European Russia from late $17^{\text {th }}$ century to 1914]. Moscow: AN SSSR, 1957, 213 p.

41. Sannikov S. N. Ekologiya i geografiya estestvennogo vozobnovleniya sosny obyknovennoy [Ecology and geography of restoration of common pine]. Moscow: Nauka, 1992, $262 \mathrm{p}$.

42. Evstigneev O. I., Korotkov V. N. Byulleten' Bryanskogo otdeleniya Russkogo botanicheskogo obshchestva [Bulletin of Bryansk department of Russian botanical society]. 2013, no. 1 (1), pp. 31-41.

43. Abaturov A. M. Poles'ya Russkoy ravniny v svyazi s problemoy ikh osvoeniya [Forest areas of Russian plain from the point of view of their development]. Moscow: Mysl', 1968, $246 \mathrm{p}$.

44. Levina R. E. Sposoby rasprostraneniya plodov i semyan [Ways of disseminating of fruits and seeds]. Moscow: Izd-vo MGU, 1957, 360 p. 
45. Evstigneev O. I., Voevodin P. V., Korotkov V. N., Murashev I. A. Uspekhi sovremennoy biologii [Achievements of modern biology]. 2013, vol. 133 (4), pp. 392-400.

46. Serebryakov I. G. Ekologicheskaya morfologiya rasteniy. Zhiznennye formy pokrytosemennykh $i$ khvoynykh rasteniy [Ecological morphology of plants: life forms of metasperm and coniferous plants]. Moscow: Vyssh. shk., $1962,378 \mathrm{p}$

47. Tsyganov D. N. Fitoindikatsiya ekologicheskikh rezhimov v podzone khvoyno-shirokolistvennykh lesov [Phytoindication of ecological regimes in the subzone of mixed coniferous-broad leaved forests]. Moscow: Nauka, 1983, $198 \mathrm{p}$.

48. Mertts P. A. Byulleten' Moskovskogo obshchestva ispytateley prirody. Otdel biologicheskiy [Moscow Society of Naturalists News. Biological series]. 1951, vol. 56, no. 5, pp. 31-44.

49. Kirikov S. V. Ptitsy i mlekopitayushchie v usloviyakh landshaftov yuzhnoy okonechnosti Urala [Birds and mammals in conditions of southern Urals landscape]. Moscow: Izd-vo AN SSSR, 1952, $412 \mathrm{p}$

50. Novikov G. A. Rol' zhivotnykh v zhizni lesa [The role of animals in the life of forests]. Moscow: Izd-vo MGU, 1956, pp. 6-165.

51. Semenov-Tyan-Shanskiy O. I. Trudy Laplandskogo gosudarstvennogo zapovednika [Proceedings of Lapland Nature Reserve]. Moscow: Glavnoe upravlenie okhotnich'ego khozyaystva i zapovednikov pri Sovete Ministrov RSFSR, 1959, iss. 5, 319 p.

52. Formozov A. N. Zveri, ptitsy i ikh vzaimootnosheniya so sredoy obitaniya [Animals, birds and their relationships with the habitat]. Moscow: Nauka, 1976, 309 p.

53. Averin Yu. V., Ganya I. M., Uspenskiy G. A. Ptitsy Moldavii [Moldova birds]. Kishinev: Shtiintsa, 1971,236 p.

54. Kaletskiy A. A. Biologiya i promysel losya [Biology and moose cropping]. Moscow: Rossel'khozizdat, 1965, pp. 113-135.

55. Samarskiy S. L., Boyko N. Ya. Izuchenie resursov nazemnykh pozvonochnykh fauny Ukrainy [Studying resources of terrestrial vertebrate species of the Ural fauna]. Kiev: Nauk. dumka, 1969, pp. 99-101.

56. Medvedi: buryy medved', belyy medved', gimalayskiy medved'. Razmeshchenie zapasov, ekologiya, ispol'zovanie i okhrana [Bears: brown bear, white bear, Himalayan bear. Location of reserves, ecology, use and preservation]. Moscow: Nauka, 1993, 519 p.

57. Evstigneev O. I., Voevodin P. V. Sovremennye problemy populyatsionnoy ekologii, geobotaniki, sistematiki i floristiki [Modern issues of population ecology, geobotany, systematics and floristry]. Kostroma: KGU im. N. A. Nekrasova, 2011, vol. 2, pp. 11-13.

58. Dunin V. F. Zapovedniki Belorussii [Nature reserves of Belarus . Minsk: Uradzhay, 1981, iss. 5, pp. 74-79.

59. Kaz'min V. D., Smirnov K. A. Byulleten' Moskovskogo obshchestva ispytateley prirody. Otdel biologicheskiy [Moscow Society of Naturalists News. Biological series]. 1992, vol. 97, no. 2, pp. 26-35.

60. Nechaev V. A. Byulleten' Moskovskogo obshchestva ispytateley prirody. Otdel biologicheskiy [Moscow Society of Naturalists News. Biological series]. 2001, vol. 106, no. 2, pp. 14-21.

61. Evstigneev O. I., Murashev I. A., Korotkov V. N. Lesovedenie [Forest science]. 2016, no. 5, pp. 384-392.

62. Pogrebnyak P. S. Obshchee lesovodstvo [General forestry]. Moscow: Kolos, 1968, 440 p.

63. Remezov N. P., Pogrebnyak P. S. Lesnoe pochvovedenie [Forest science]. Moscow: Lesnaya promyshlennost', $1965,324 \mathrm{p}$

64. Kosenko S. M., Kaygorodova E. Yu. Byulleten' Moskovskogo obshchestva ispytateley prirody. Otdel biologicheskiy [Moscow Society of Naturalists News. Biological series ]. 2000, vol. 105, no. 1, pp. 21-26.

65. Evstigneev O. I., Korotkov V. N., Belyakov K. V., Braslavskaya T. Yu., Romanovskiy A. M., Rubashko G. E., Sarycheva E. P., Fedotov Yu. P. Biogeotsenoticheskiy pokrov Nerusso-Desnyanskogo Poles'ya: mekhanizmy podderzhaniya biologicheskogo raznoobraziya [Biogeocenotic cover of Nerussa-Desna Polesie: mechanisms of maintaining biological diversity]. Bryansk: Zapovednik «Bryanskiy les», 1999, 176 p.

66. Evstigneev O. I. Lesovedenie [Forest science]. 1996, no. 6, pp. 26-35.

67. Evstigneev O. I. Strukturno-funktsional'naya organizatsiya i dinamika rastitel'nogo pokrova [Structural and functional organization and dynamics of vegetation cover]. Samara: Izd-vo Povolzh. sots.-gum. akad., 2012, pp. 181-184. 